Review

\title{
The Prodrug Approach: A Successful Tool for Improving Drug Solubility
}

\author{
Daniela Hartmann Jornada, Guilherme Felipe dos Santos Fernandes, Diego Eidy Chiba, \\ Thais Regina Ferreira de Melo, Jean Leandro dos Santos and Man Chin Chung *
}

Received: 14 October 2015 ; Accepted: 15 December 2015 ; Published: 29 December 2015

Academic Editors: Thomas Rades, Holger Grohganz and Korbinian Löbmann

Faculdade de Ciências Farmacêuticas, UNESP_University Estadual Paulista, Rodovia Araraquara Jaú Km 01, 14801-902 Araraquara, São Paulo, Brasil; daniela.dhj@gmail.com (D.H.J.); guilhermefelipe@outlook.com (G.F.S.F.); chiba.diego@gmail.com (D.E.C.); trfmelo@gmail.com (T.R.F.M.); santosjl@fcfar.unesp.br (J.L.S.)

* Correspondence: chungmc@fcfar.unesp.br; Tel.: +55-16-3301-6962; Fax: +55-16-3301-6960

\begin{abstract}
Prodrug design is a widely known molecular modification strategy that aims to optimize the physicochemical and pharmacological properties of drugs to improve their solubility and pharmacokinetic features and decrease their toxicity. A lack of solubility is one of the main obstacles to drug development. This review aims to describe recent advances in the improvement of solubility via the prodrug approach. The main chemical carriers and examples of successful strategies will be discussed, highlighting the advances of this field in the last ten years.
\end{abstract}

Keywords: prodrug; solubility; water-soluble prodrugs; solubility of prodrugs; molecular modification

\section{Introduction}

Poor solubility is one of the main problems faced by researchers during drug development. Commonly, even with the use of current computational "filters" to minimize this problem, compounds that are active in vitro may lack adequate pharmacokinetic properties and/or may be difficult to formulate [1]. A study conducted with the top 200 oral drug products in Japan, Great Britain, United States and Spain revealed that approximately $37 \%$ of drugs had solubilities of less than $0.1 \mathrm{mg} / \mathrm{mL}$. One explanation may include the need for drugs that are highly potent in low doses, however, this issue represents a challenge in drug discovery [2].

Although the prodrug approach is often considered only when the prototype presents unexpected problems, this strategy offers a versatile approach to drug development and should not be considered a last resort. The prodrug approach is a promising molecular modification by which drug developers and designers can modulate drug pharmacokinetics, pharmacodynamics and toxicology [3].

A prodrug is a poorly active or inactive compound containing the parental drug that undergoes some in vivo biotransformation through chemical or enzymatic cleavage, enabling the delivery of the active molecule at efficacious levels $[1,3,4]$. Prodrugs are conventionally classified in two major classes: carrier-linked prodrugs and bioprecursors. Carrier-linked prodrugs can be classified as bipartite prodrugs, in which the carrier is linked directly to the parent drug, and tripartite prodrugs, in which a spacer links the carrier to the parent drug [5]. Carriers are commonly attached by chemical groups such as ester, amide, carbamate, carbonate, ether, imine, phosphate, among others [1,6,7] (Figure 1). Mutual prodrugs are a type of carrier-linked prodrug in which two active compounds are linked each acting as the carrier to the other. These prodrugs have increased effectiveness through synergistic action $[5,8]$. Another type of carrier-linked prodrug is the macromolecular prodrug; these prodrugs use polymeric backbones as carriers. Macromolecular prodrugs are commonly used to design prodrugs that will be cleaved inside of a cell and in targeted drug-delivery systems. This approach offers improved drug 
solubility, stability, drug release and pharmacokinetics. Additionally, it can facilitate the accumulation of a drug at the site of action and improve safety $[9,10]$. Bioprecursors are inactive compounds that do not have a carrier and are rapidly converted to an active drug after metabolic reactions (normally redox reactions) $[5,8]$.

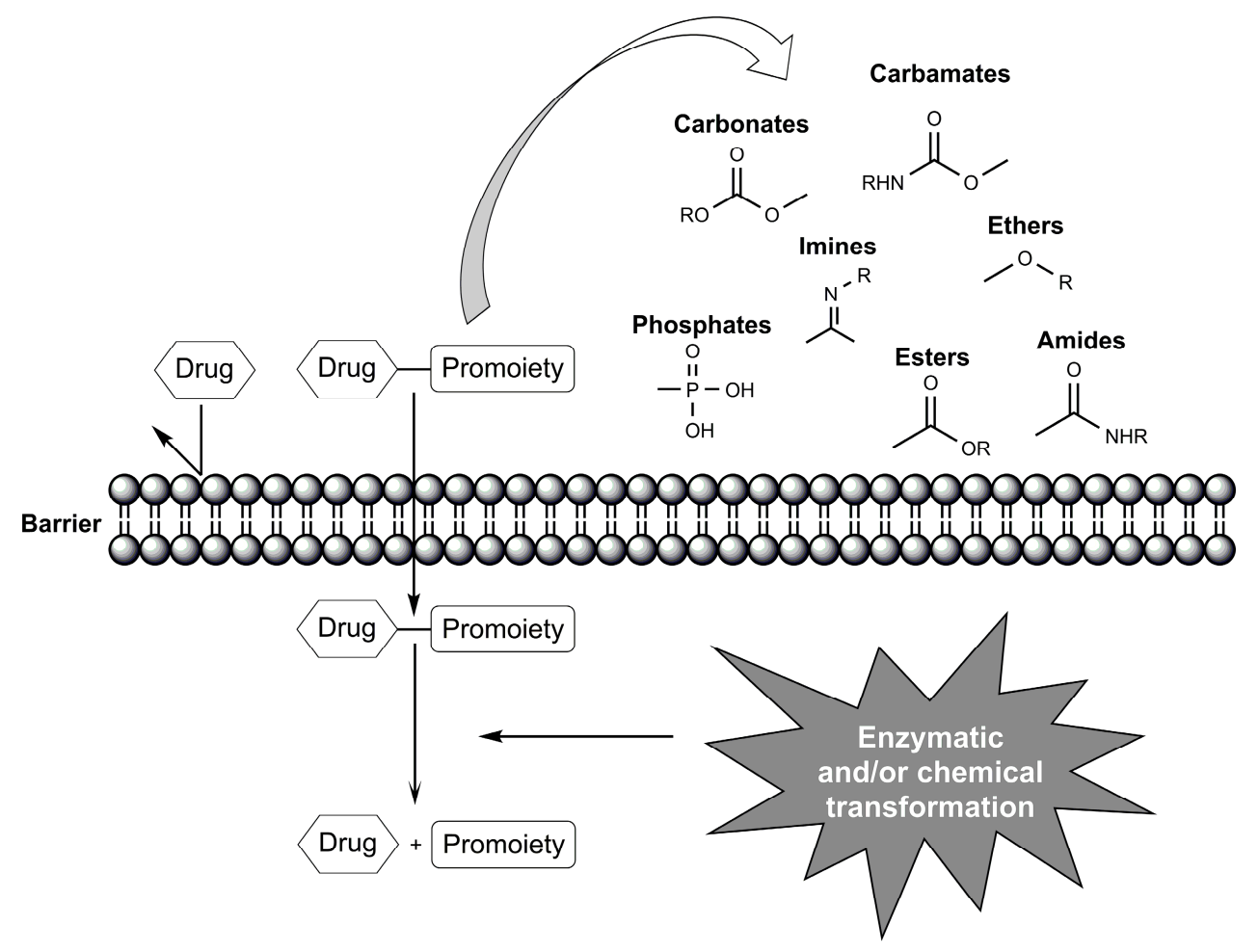

Figure 1. In vivo bioactivation of prodrugs by enzymatic and/or chemical transformations.

Undesirable properties, including poor aqueous solubility, chemical instability, insufficient oral or local absorption, fast pre-systemic metabolism, low half-life, toxicity and local irritation are commonly resolved using the prodrug approach. In addition, problems related to drug formulation and delivery can also be overcome by using this strategy [1,11-13]. Occasionally, strategies such as particle-size reduction, solubilizing excipients, complexation agents and use of surfactants fail to improve the solubility in water profile and reduce toxicity to desirable levels [13,14]. For example, some surfactants used in parenteral formulations frequently have toxic effects such as anaphylactic reactions [14].

However, in some cases, low-solubility compounds yield false-positive results on in vitro assays due to non-specific binding [15]. Moreover, in clinical trials, low-solubility drugs can lead to precipitation and crystalluria, raising additional safety concerns. Poorly soluble drugs have recently been discontinued in clinical assays for this reason $[15,16]$.

For these reasons, the prodrug approach presents a safe and effective strategy by which to improve the solubility of drugs. This review aims to present the latest strategies in prodrug design used to obtain water-soluble compounds for oral and parenteral uses. We selected research from the last ten years (2005 through August of 2015) showing increased solubility through the prodrug approach. In the literature search, we used the following terms: "water-soluble prodrugs", "increased solubility prodrugs" and "enhanced solubility prodrugs" in published databases including PubMed, LILACS, Scielo, Cochrane, Web of Science and Scopus.

\section{Ester Prodrugs}

The features of an ideal prodrug include the following: (a) hydrolysis resistance during absorption; (b) weak or no activity; (c) aqueous solubility; (d) good permeability through the cells; (e) chemical 
stability at different pHs; (f) kinetics that allow release of the parental drug [17]. Among the chemical bonds used to link the parental drug and carrier, esters have proven to be promising due to their amenability to hydrolysis both in vivo and in vitro. Some examples of the use of esters in prodrug design are discussed below.

The enzyme thioredoxin-thioredoxin reductase plays an important role in thioredoxin system by catalyzing the reduction of thioredoxin. Specifically, the thioredoxin system participates in protecting DNA against oxidative damage and has been implicated in several diseases, including cancer and rheumatoid arthritis [18]. Among the described inhibitors, the naphthoquinone spiroketal compound palmarumycin (1) has shown in vitro anticancer activity; however, it failed in in vivo assays. The authors hypothesized that the lack of activity could be due to its high lipophilicity; therefore, they designed prodrugs containing amino-esters and two morpholine analogues. The glycyl ester derivative 2 (Figure 2) was more than seven times more soluble in water than its parent drug. Despite the higher solubility compared to the parent drug, the compound did not exhibit superior activity compared to palmarumycin $\mathrm{CP}_{1}[19]$.<smiles>O=C1C=CC2(Oc3cccc(O)c31)Oc1cccc3c(O)ccc(c13)O2</smiles>

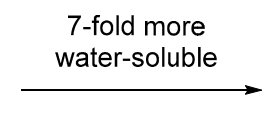

Palmarumycin Solubility: $0.1 \mathrm{mg} / \mathrm{mL}$

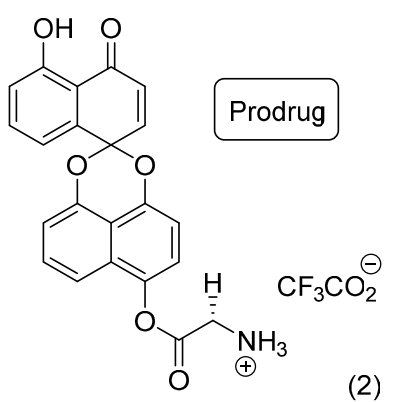

Solubility: $0.7 \mathrm{mg} / \mathrm{mL}$

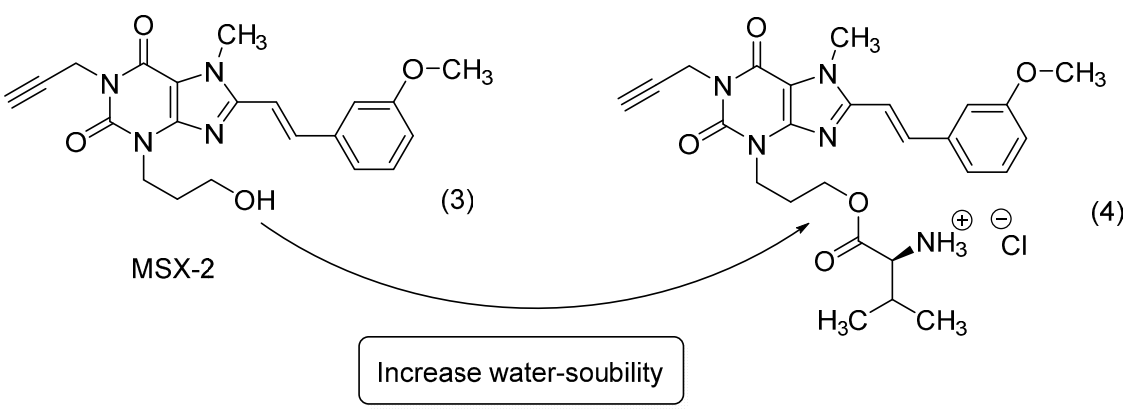

(4)

Figure 2. Glycyl ester and amino-acid-ester prodrugs [19,20].

The adenosine $A_{2 A}$ receptor is a G-protein-coupled receptor expressed at high levels in blood platelets, GABAergic neurons, and cells of the thymus, the olfactory bulb and the spleen. This receptor has been widely known as a target since the approval of the drug regadenoson by the U.S. Food and Drug Administration (FDA). Among the activities described for adenosine antagonists are neuroprotective, antidepressant, and analgesic effects. In addition, this receptor has been explored as a target of new therapeutic agents to treat Parkinson's disease [21]. Compound 3, known as MSX-2 (Figure 2), is a potent and selective antagonist of the adenosine $\mathrm{A}_{2 \mathrm{~A}}$ receptor [22,23]. Despite its in vitro activity, this molecule shows low solubility in water, hindering in vivo studies. Two different approaches were undertaken to resolve this issue. The first involved the introduction of a phosphate subunit to increase solubility. Phosphate prodrugs have shown high solubility in water; however, it is not readily absorbed by the oral route. The second approach involved the introduction of amino acids, specifically L-valine. The solubility in water of compound 4 (Figure 2), as evaluated by a spectrophotometric method is $7.3 \mathrm{mg} / \mathrm{mL}$, less than that of the phosphate prodrug $(9.0 \mathrm{mg} / \mathrm{mL})$ but 
superior to that of the parent drug. According to the authors, the valine prodrug was stable in aqueous solution at room temperature for up to four days; however, in the presence of pig liver esterase, the compound undergoes bioconversion, releasing the parental drug, with a half-life of $6.9 \mathrm{~min}$ [20].

New water-soluble antiviral compounds also use ester amino-acid prodrugs to increase solubility with a bicyclic nucleoside subunit. This scaffold was initially described as a by-product of the condensation of 5-iodo nucleosides within terminal alkynes catalyzed by palladium; however, in vitro studies revealed activity against several viruses, including herpes simplex (type 1 and type 2), varicella zoster and cytomegalovirus. One of the most active compounds was the $p$-penthylphenylbicyclic nucleoside analogue Cf1743; however, its low solubility in water limits its use [24]. The prodrug approach was used to resolve this limitation, with dipeptides as carriers of Cf1743 (Val, Asn, Lys, Asp) (Figure 3). The amino-acid pro-residue is recognized by the enzyme dipeptidyl-peptidase IV (DPPIV/CD26), which is expressed in leukocytes as well as epithelial, endothelial and fibroblast cells. It was hypothesized that leukocyte enzymes would activate the prodrug. Interestingly, the authors found an analog 5 with 4000-fold greater solubility in water and 7-15-fold greater bioavailability compared to the parent drug [25].

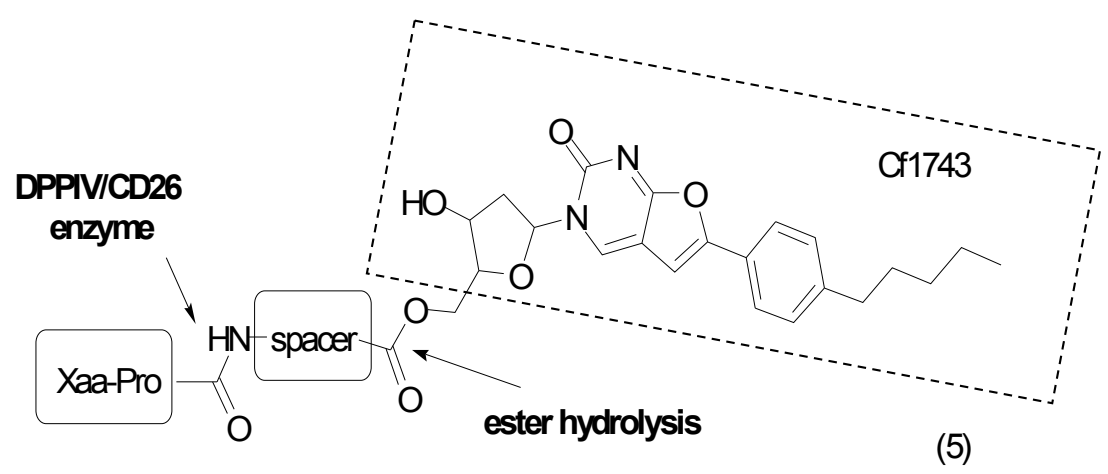

Xaa- Val, Asn, Lys, Asp
Spacer- Val, Ala, Leu, Phe

Figure 3. Bicyclic furanopyrimidine nucleoside analogue [25].

Amino acids were also used to improve the physicochemical properties of oleanolic acid (6). This triterpenoid molecule is a natural product found in Asian herbs whose pharmacological effects include anti-inflammatory, analgesic and antitumoral activities. Despite these effects, oleanolic acid has low bioavailability in rats $(7 \%)$, probably due to its low solubility in water $(0.0012 \mu \mathrm{g} / \mathrm{mL})$. Attempts to improve the solubility using different formulations failed, probably due to its low permeability. To explore the transporters involved in the absorption of oleanolic acid, the researchers designed a series of prodrugs intended to be recognized by the PepT1 transporter. This transporter is important in drug absorption because it improves bioavailability. One commercially successful prodrug that exploits this transporter is valaciclovir, which has improved bioavailability (55\%) compared to its parental drug, acyclovir $(15 \%-20 \%)$ [26-28]. This transporter could also improve the absorption of oleanolic-acid derivatives. A series of novel ethylene-glycol-linked amino-acid-diester prodrugs of oleanolic acid was synthesized and tested for solubility and pharmacokinetic profile. Six analogs showed improved solubility in water. The compound 7 containing an L-valine subunit (Figure 4) was the most promising analog, exhibiting solubility greater than $25 \mu \mathrm{g} / \mathrm{mL}$ and increased intestinal perfusion and oral bioavailability in rats [29]. In a different paper, the same research group described a series of seven propylene glycol-linked amino-acid/dipeptide-diester prodrugs of oleanolic acid. In this study, propylene glycol (PEG) was chosen as a spacer due to its very low toxicity in vivo. The authors synthesized seven diester prodrugs and evaluated the influence of the linker on pharmacokinetic 
properties. Compound 8 was the most water soluble (up to $1.0 \mathrm{mg} / \mathrm{mL}$; Figure 4). Compared to ethylene-glycol derivatives, the propylene-glycol series was the most soluble, stable and bioavailable and had the greatest affinity for the PepT1 enzyme [30].

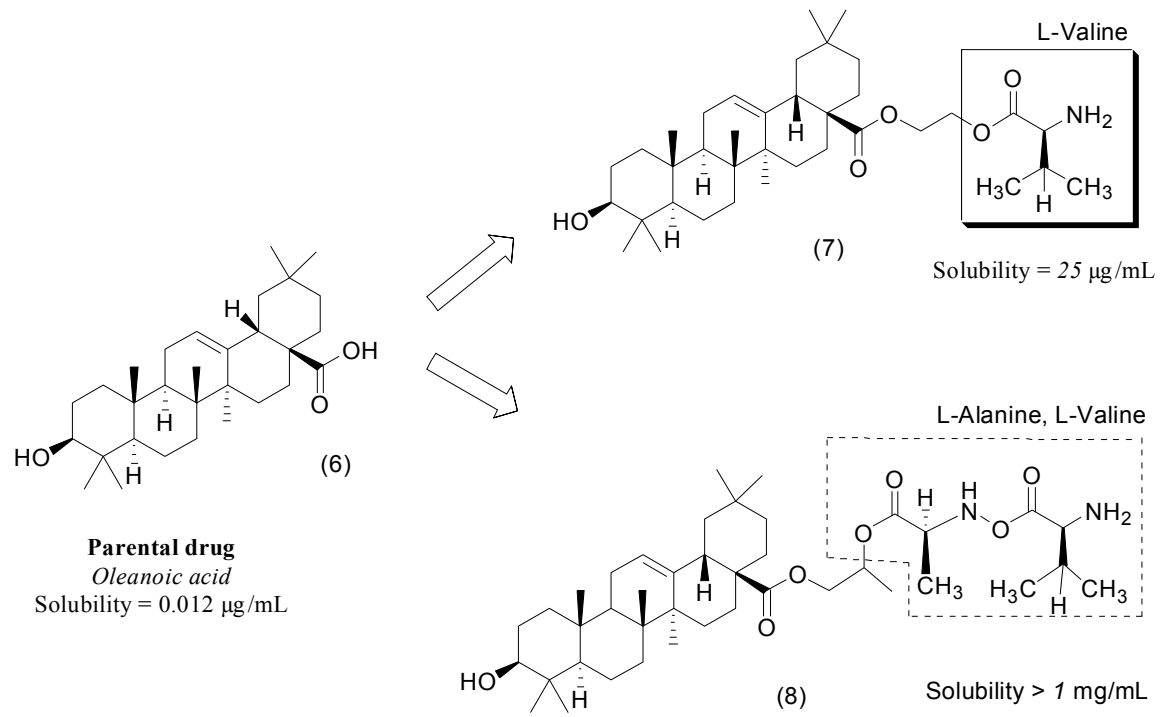

Figure 4. Ethylene glycol and propylene glycol prodrugs of oleanoic acid [29,30].

Another terpenoid with low solubility in water whose properties were enhanced by the use of the prodrug approach is oridonin (9). This natural product is found in Rabdosia rubescens, a Chinese medicinal plant, and it exhibited antitumoral activity against several types of cancer, including leukemia [31,32]. Exploring polyethylene glycol as carrier, the authors linked oridonin to PEG, using succinic acid as a spacer. Four different molecular weights of PEGs were tested to increase solubility in water. The greatest increase in solubility was observed for a low PEG-molecular-weight (5 kDa) conjugate 10 (Figure 5). This prodrug had 99.2 times the solubility of oridonin. A chemical hydrolysis study showed a sustained-release effect for the prodrugs. In vivo studies using the two intermediate conjugates (10 and $20 \mathrm{kDa}$ ) demonstrated a successful use of this prodrug approach, as these derivatives have better pharmacokinetic profiles than oridonin [33].
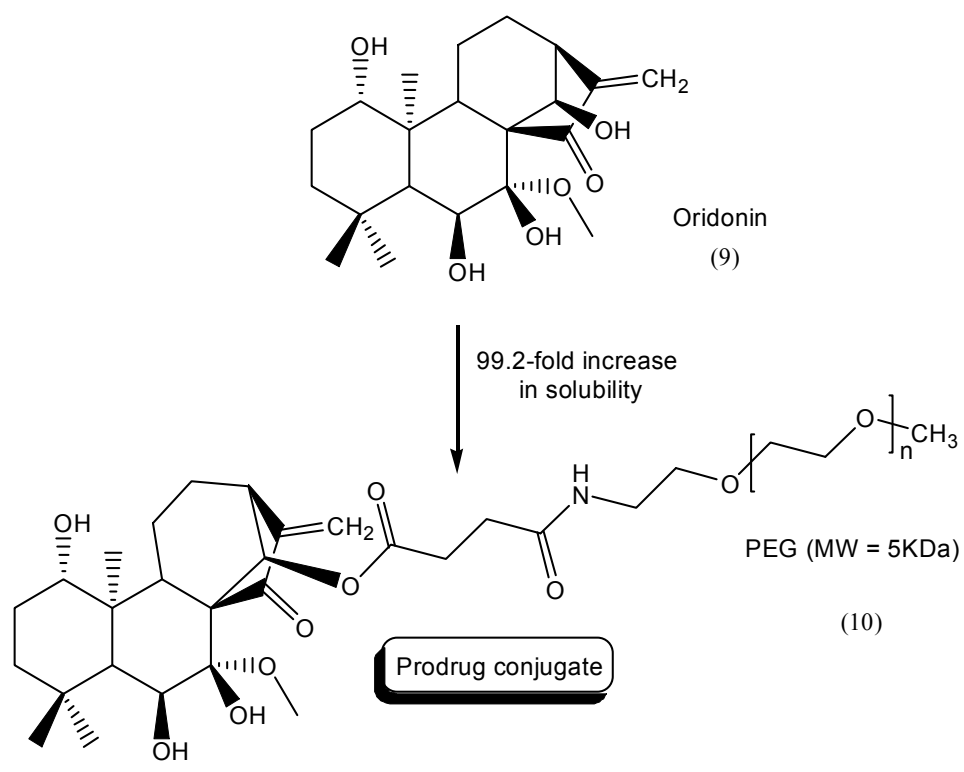

Figure 5. PEG prodrugs of oridonin [33]. 
A similar approach exploring the use of PEG to increase solubility was carried out using another anticancer compound, gambogic acid (11). This natural product inhibits tumor growth and induces apoptosis in various cancer cells [34]. The authors synthesized a series of PEGylate prodrugs 12 with molecular weights of $2 \mathrm{kDa}, 4 \mathrm{kDa}, 10 \mathrm{kDa}$ and $20 \mathrm{kDa}$ using L-leucine as a spacer (Figure 6). The solubility in water ranged from $645 \mathrm{mg} / \mathrm{mL}$ to $1750 \mathrm{mg} / \mathrm{mL}$. The most soluble prodrug contained PEG-2 kDa-L-leucine-GA. For all prodrugs, the half-life measured in plasma ranged from 1.26 to $6.12 \mathrm{~h}[35]$.

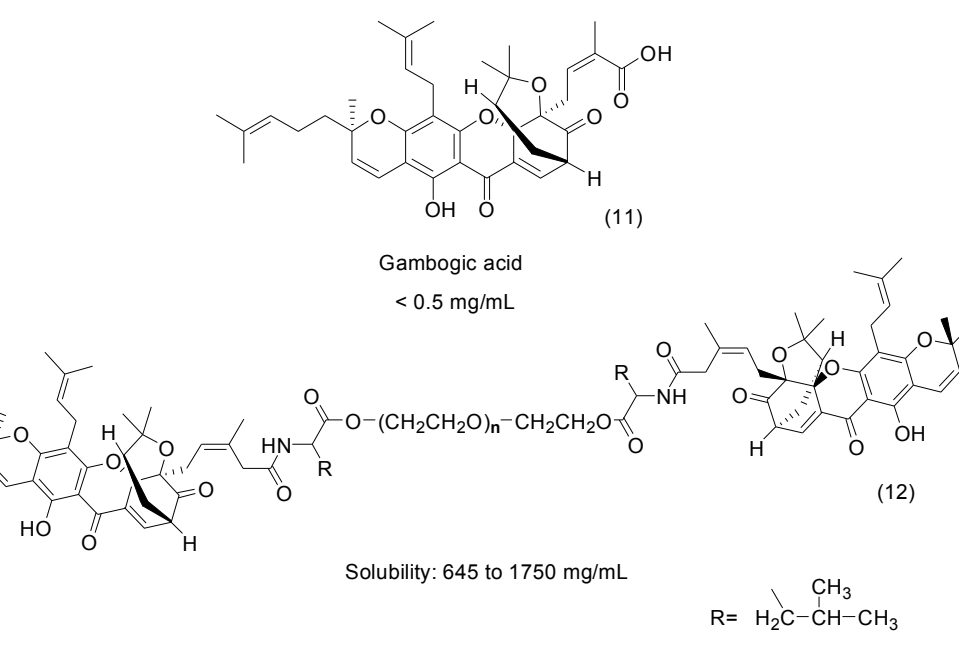

Figure 6. General structure of gambogic-acid PEG prodrugs [35].

The poor solubility in water of taxoids is well established in the literature [36]. Using the prodrug approach, Skwarczynski et al., synthesized prodrugs whose solubilities ranged from 0.8 to $1.1 \mathrm{mg} / \mathrm{mL}$. Interestingly, the authors identified a novel mechanism of parental-drug release: a $\mathrm{pH}$-dependent $\mathrm{O}-\mathrm{N}$ intramolecular acyl migration reaction (Figure 7). This strategy increased the stability of taxoids, released the parental drug at $\mathrm{pH} 7.4$ and improved drug solubility. Some of these prodrugs containing the $2^{\prime}$-O-isoform of taxoids, such as compound 14, exhibited 4000 -fold greater solubility than the parent drug 13 [37].
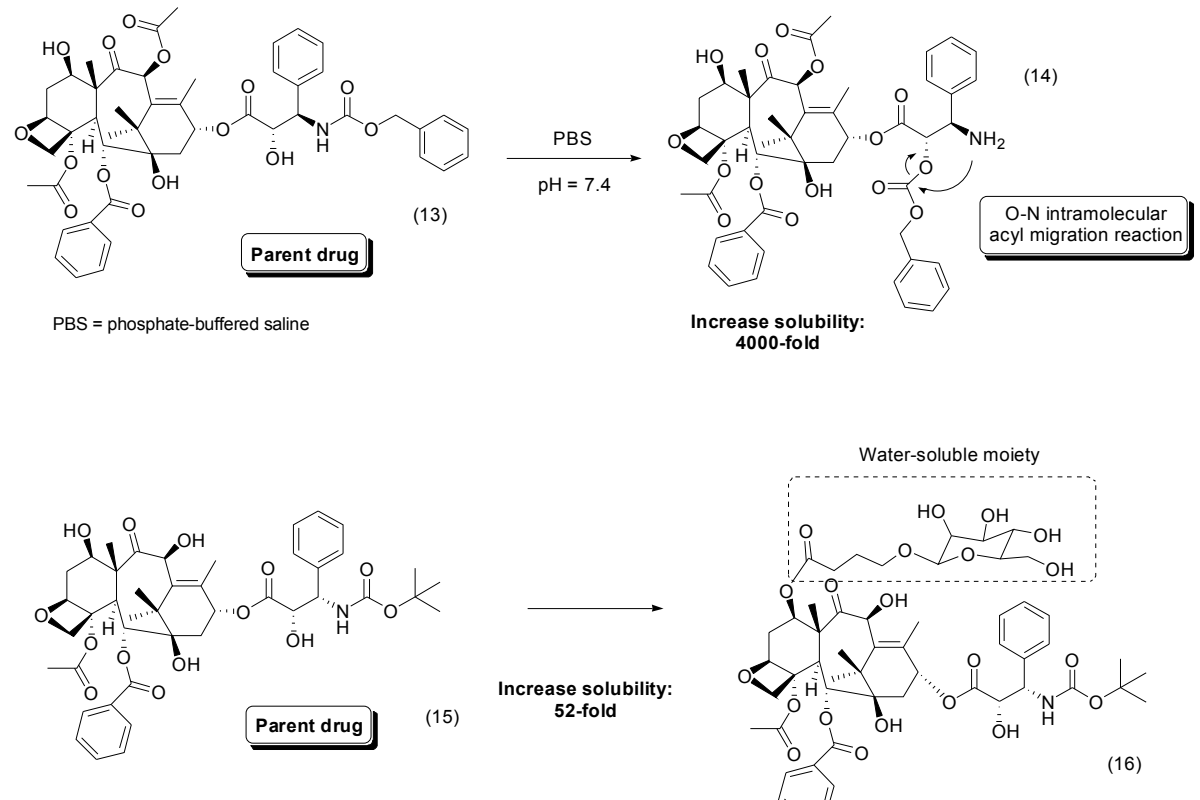

Figure 7. Taxoid prodrugs [37,38]. 
One approach to improve the solubility of taxoids used docetaxel-glycopyranoside ester-linked prodrugs. The compounds were prepared by chemo-enzymatic reactions using $\beta$-xylosidase, lactase and $\beta$-galactosidase. All of them demonstrated improved solubility in water compared to the parental drug, docetaxel, 1 and the best compound 16 showed a 52-fold increase (Figure 7). In addition, the compounds were able to release the parental drug in vitro and exhibited cytotoxic effects against KB and MCF-7 human cancer cell lines [38].

A paclitaxel prodrug containing a disulfide moiety was described by Gund et al., as an anticancer compound. The rationale behind the design of these molecules is based on the recognition of disulfide subunit by the enzyme glutathione, which releases the paclitaxel (17). High levels of this enzyme have been described in cancer cells, and one hypothesis speculates that this enzyme is involved in resistance to many anticancer drugs $[39,40]$. The prodrug compounds were 6-100 times more soluble than paclitaxel. Moreover, the most active compound 18 (Figure 8) was 65 times more water soluble than paclitaxel. For this molecule, superior antitumoral activity was identified in all types of cells evaluated, except for MCF10A. After oral administration, the bioavailability in mice was five-fold greater than that of the parental drug [41].

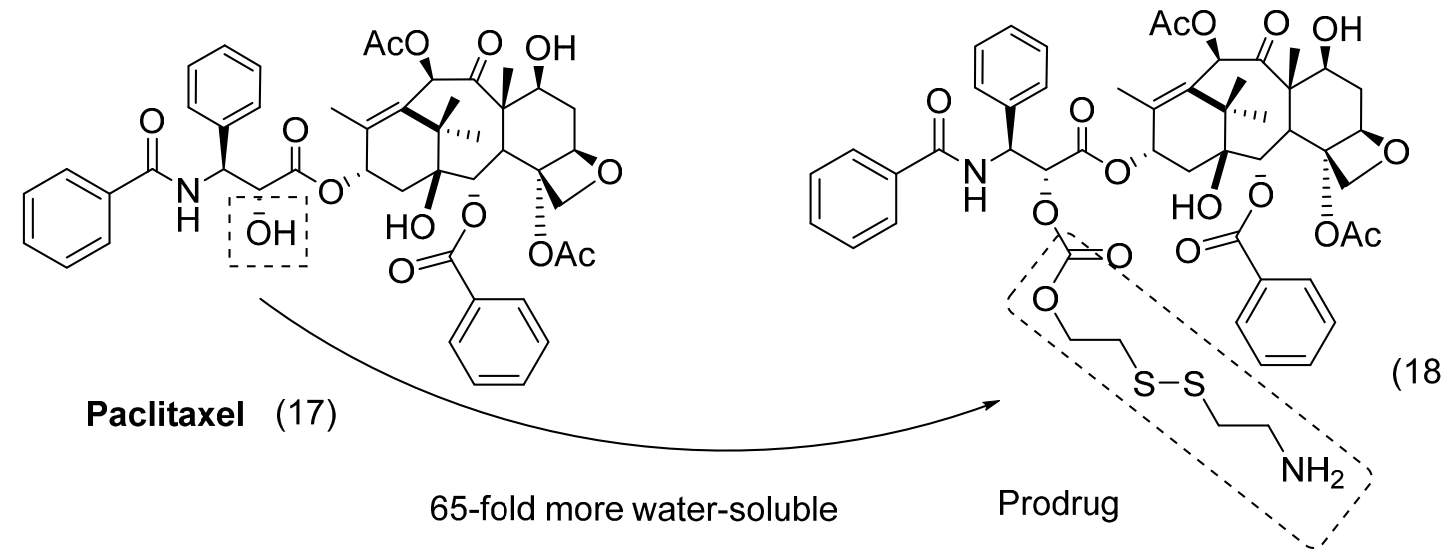

Figure 8. Paclitaxel-disulfide prodrug with anticancer activity [41].

Etoposide (19) is a topoisomerase inhibitor with variable pharmacokinetics and low solubility in water. Using the prodrug approach, a series of water-soluble etoposide ester prodrugs were produced. These prodrugs with an attached malic acid demonstrated solubility in water 23 to 120-fold greater than that of the parental drug. In addition, the most active compound 20 (Figure 9), demonstrated in vitro cytotoxic effects comparable to those of etoposide [42].

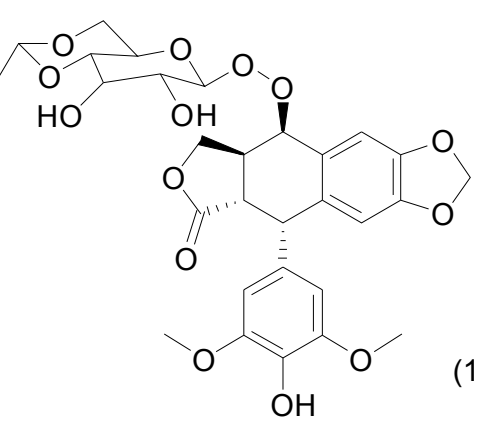

Parental drug - Etoposide Water-solubility $0.1 \mathrm{mg} / \mathrm{mL}$

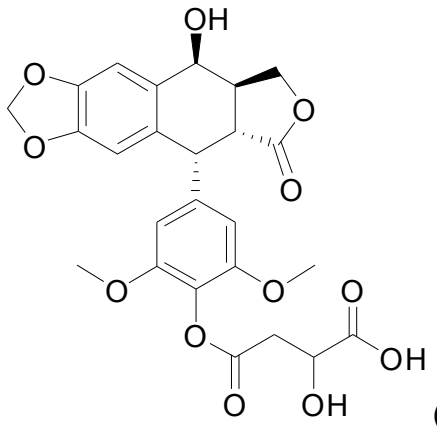

\section{Prodrug}

Water-solubility $9.0 \mathrm{mg} / \mathrm{mL}$

Figure 9. Etoposide ester prodrugs containing malic acid [42]. 
Non-steroidal anti-inflammatory drugs (NSAIDs) are widely prescribed worldwide. The use of NSAID-ester prodrugs is extensively reported in the literature. Controversially, some authors report that the esterification of NSAIDs can reduce the adverse gastric effects by masking the carboxylic acid function; however, the changes in the pharmacokinetic profile that provide sustained release can explain in part the reduced adverse effects seen in some cases [43,44]. In many cases, the lack of solubility limits the use and worsens the adverse effects of NSAIDs. Therefore, to improve the solubility in water of the NSAID 6-methoxy-2-naphthylacetic acid (6-MNA, 21), a series of ester prodrugs intended for percutaneous drug delivery was designed and synthesized. The authors designed piperazine derivatives attached by an ester linkage to enhance the solubility of these compounds. They identified a compound 22 that proved to be water soluble and 11.2-fold more permeable through the skin than 6-MNA at pH 7.4 (Figure 10) [45].

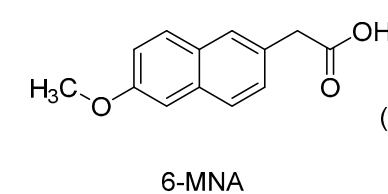

Solubility: $0.78 \mu \mathrm{M}$ at $\mathrm{pH} 5.0$ (water)

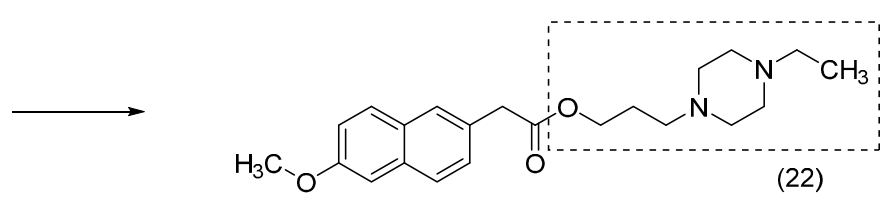

Increase 20-fold the water solubility
Solubility: $16.30 \mu \mathrm{M}$ at pH 5.0 (water)<smiles>O=C(O)Cc1ccccc1Nc1c(Cl)cccc1Cl</smiles>

(23)

Parent drug $=$ Diclofenac Solubility $=0.0034 \mu \mathrm{mol} / \mathrm{mL}$ (0.02 M phosphate buffer $\mathrm{pH} 2.5$ )

Figure 10. NSAID ester prodrugs [45,46].

Exploring transdermal delivery, Lobo et al., have synthesized and evaluated series of diclofenac (23)-ester prodrugs. The most promising compound, glycerol diclofenac ester (24), demonstrated better solubility, a lower partition coefficient and higher flux across the skin than its parental drug (Figure 10). In vitro studies using rat plasma showed rapid conversion of prodrugs to diclofenac due to the activity of esterases [46].

The natural product quercetin (25) exhibited promising anti-inflammatory properties; however, its low skin permeation limits its use [47]. Therefore, to improve the passage of quercetin through the skin, a series of prodrugs was synthesized and evaluated. The researchers observed that prodrugs with long acyl chains were less soluble than the parent drug. However, compounds with shorter acyl chains were more water soluble, with an increase of 64-fold for compound 26. Thus, the prodrug exhibited greater solubility and skin permeation than quercetin (Figure 11) [48].

$2 R$ - $\gamma$-Tocotrienol $(\gamma$-T3), which is present in vitamin $\mathrm{E}$, and has antioxidant activity against brain microsomes and nitric oxide and inhibits cholesterol increases and cancer proliferation [49-58]; however, $\gamma$-T3 is poorly soluble in aqueous solutions, impairing its pharmacological use. Three aminoalkylcarboxylic acid esters generated as water-soluble prodrugs of $\gamma$-T3 showed better solubility in water compared to the parental drug. Compound 27 (Figure 11) was the most promising for parenteral use, with high solubility in water, stability and rapid hydrolysis in rat and human plasma, making it a good potential alternative for cancer therapy [59]. 


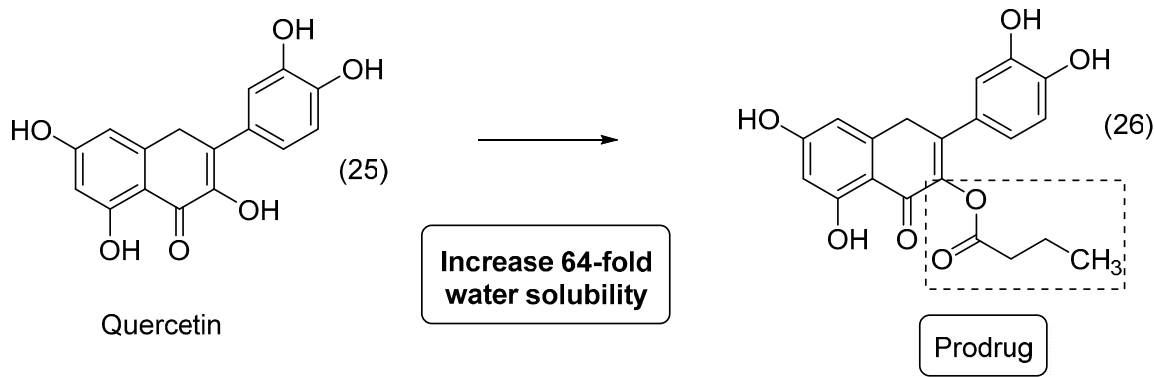

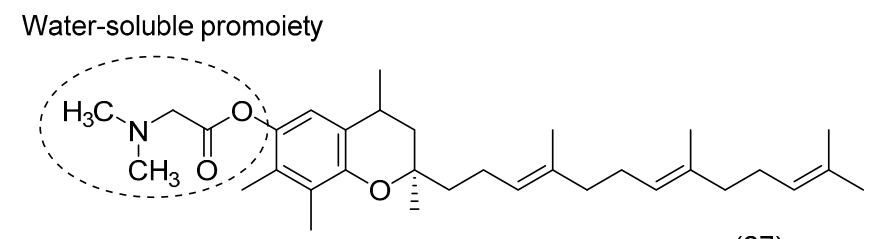

Figure 11. Prodrugs of quercetin and $\gamma$-T3 [48,59].

Screening of an in-house library was used to identify compound 28 as a promising candidate targeting Human Immunodeficiency Virus (HIV) replication; however, its poor solubility in water limits additional preclinical pharmacokinetic studies. Therefore, researchers have designed novel indazole derivatives. The most active molecule 29 (Figure 12) contains an $\mathrm{N}$-acyloxymethyl group as a pro-moiety and was 300 -fold more water soluble than its parent compound. Additionally, this prodrug was more active against $\mathrm{HIV}$, exhibiting an $\mathrm{EC}_{50}$ of $2 \mu \mathrm{M}$, while the parental drug showed an $\mathrm{EC}_{50}$ of $3 \mu \mathrm{M}[60]$.

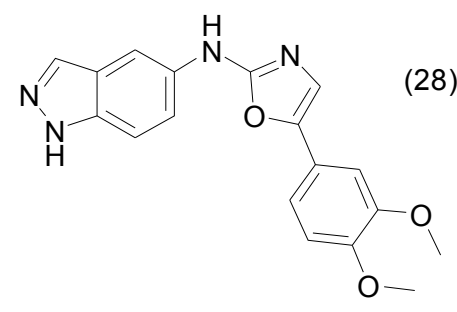

Parent drug

Solubility: $0.2 \mu \mathrm{M}$

(phosphate buffer at $\mathrm{pH} 7.4$ )

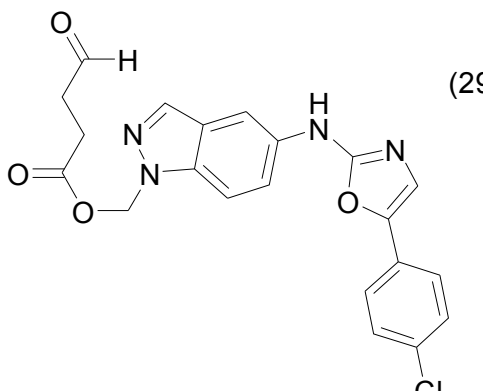

Prodrug

Solubility: $60 \mu \mathrm{M}$

(phosphate buffer at $\mathrm{pH} 7.4$ )

Figure 12. N-acyloxymethyl ester prodrug [60].

\section{Amide Prodrugs}

Acyclovir (30) is an antiviral drug that has poor solubility in water and also has low bioavailability (between 10\% and 20\%) [61]. To improve these characteristics, two peptide prodrugs, an amide 31 and an ester prodrug 32 were developed (Figure 13). The first was designed to release acyclovir directly through the action of enzyme dipeptidyl peptidase IV (DPPIV or CD26), and the second requires two steps to release the parental drug. Both showed a significant increase in solubility (17-fold for amide and 9-fold for ester derivatives) compared to the parent drug. Furthermore, the compounds were stable in phosphate-buffered saline (PBS) and were rapidly cleaved by plasmatic enzymes. Although 
the antiviral activity was not superior to that of free acyclovir, both presented good antiviral activity against herpes simplex virus type 1 and type 2 [62].

SB-3CT (33) is a highly selective inhibitor of the endopeptidases matrix metalloproteinases 2 and 9 (MMP-2 and MMP-9), also known as gelatinases, which have attracted interest in research due to their participation in a significant number of human pathologies such as cancer, neuronal death, atherosclerosis and aneurysms [63]. Due to the limited solubility in water of SB-3CT $(2.3 \mu \mathrm{g} / \mathrm{mL})$, two series of prodrugs were developed using amino acids (Gly, L-Lys, L-Glu and L-Arg) and the dipeptide L-Arg-L-Arg as pro-moieties, linked by an ester or amide group. All prodrugs showed improved solubility in water (a more than 5000-fold increase). The ester compounds were unstable in aqueous solution, human plasma and blood, while amides demonstrated resistance to fast hydrolysis. The amide prodrugs released the active drug into the blood in $30 \mathrm{~min}$. The arginyl-amide prodrug 34 (Figure 13) was metabolically stable in mouse, rat and human liver microsomes. Moreover, the prodrug 34 was non-mutagenic in an Ames assay [64].

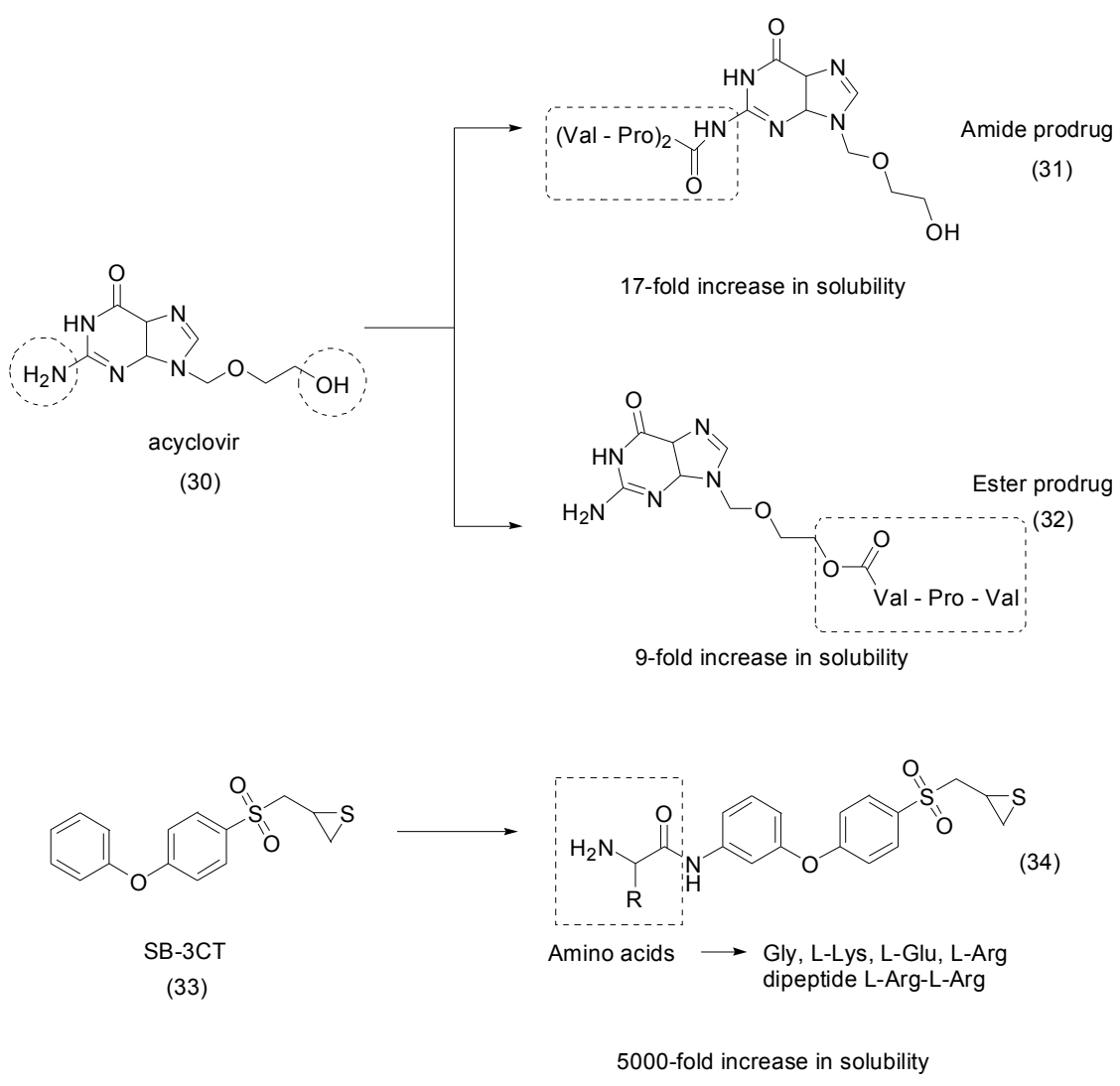

Figure 13. Peptide prodrugs of acyclovir and SB-3CT [62,64].

DW2282 (35) is a potent antiproliferative compound with a broad spectrum of action against various cancer cell lines, but in preclinical assays, this analog showed gastrointestinal toxicity [65]. A series of novel amino-acid conjugates were designed to improve the aqueous solubility of these analogs and prevent toxic effects. All synthesized compounds were more soluble and three were more active than the parental drug. The most promising analog 36 (Figure 14) had a good reconversion rate in human plasma and good bioavailability by the oral route in mice. Moreover, this molecule was more active and approximately 36-fold more soluble than DW2282 [66].

Bone tissues are difficult to treat because of limited drug delivery and retention and low sanguineous flow [67]. Hydroxyapatite (HA), a constituent of bones, can be a target for these drugs through the interaction between negative groups and the calcium ions in HA [68-71]. Researchers 
designed and evaluated the solubility and pharmacokinetic profile of novel dendritic naproxen-peptide prodrugs, specifically L-aspartate and L-glutamate.

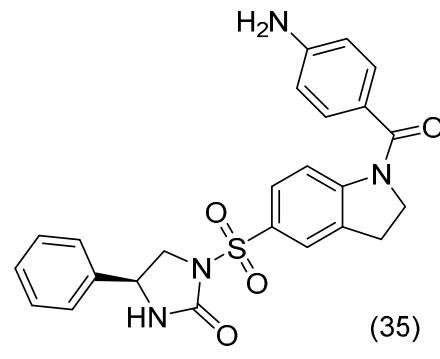

DW2282

Water-solubility: $0.024 \mathrm{mg} / \mathrm{mL}$

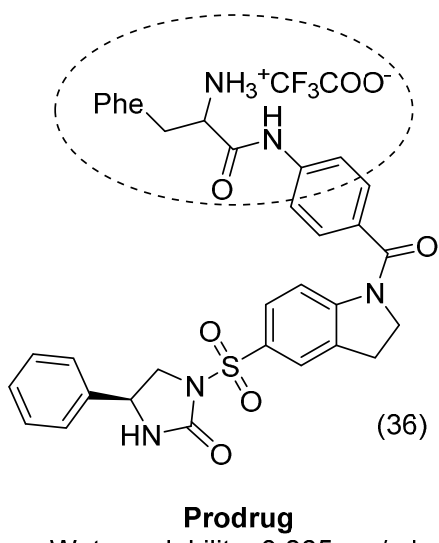

Water-solubility: $0.865 \mathrm{mg} / \mathrm{mL}$

Figure 14. Prodrug derivative of DW2282 [66].

Their solubility in water was evaluated at three different $\mathrm{pH}$ values, and the prodrugs were more soluble at increased $\mathrm{pH}$. The authors proposed that the solubility of the analogs can be related to surface area and carboxyl groups in dendritic peptides; in this way, the second-generation molecules have more interactions with water and thus are more water soluble than the first-generation drugs 39 (Figure 15). The most promising analog NAP-G2-Asp (38) attached to L-aspartate subunits showed an approximately 90 -fold increased solubility in water at $\mathrm{pH}$ 7. In the HA-binding assay, NAP-G2-Asp showed $80 \%$ binding activity in $25 \mathrm{mg} / \mathrm{mL}$ in PBS. In $50 \%$ human plasma it acted as a prodrug, rapidly and effectively releasing the parent drug [72].

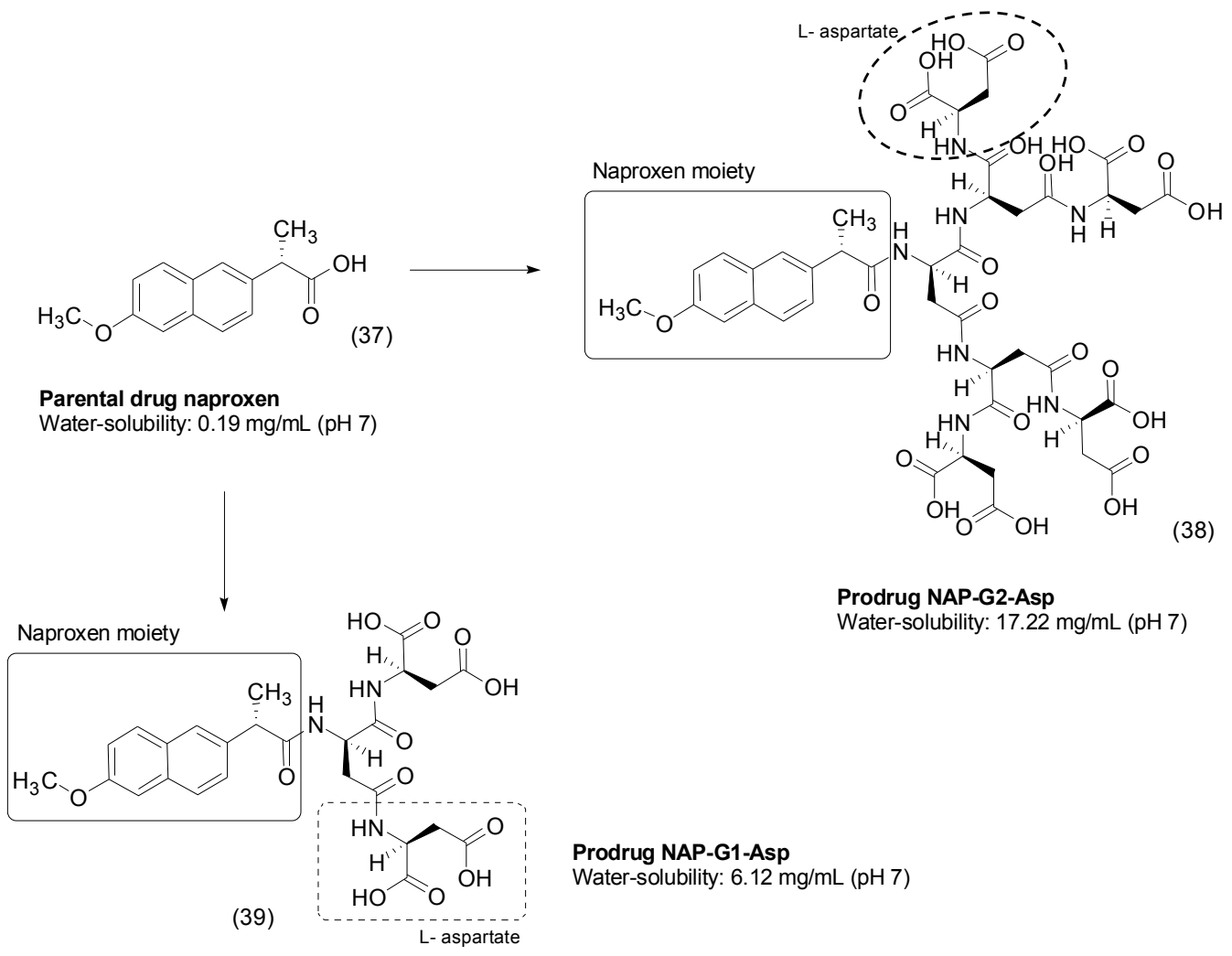

Figure 15. Dendritic naproxen-peptides prodrugs [72]. 
A benzamide derivative, PC190723 (40, Figure 16), was proposed as a potent antimicrobial agent targeting the FtsZ protein. This enzyme plays a key role in bacterial cell division, and studies suggest that it is a promising new target for antibiotic development. To overcome its poor formulation, two new prodrugs were developed. The first, the compound TXY436 (41, Figure 16) is a N-Mannich base derivative that was 2.8-fold more soluble than the parent drug in PBS ( $\mathrm{pH}=7.4)$ and 100-fold more soluble in $10 \mathrm{mM}$ citrate solution $(\mathrm{pH}=2.6)$. The latter is suitable for in vivo drug administration. Moreover, this compound is stable in citrate solution and is rapidly converted to the parent drug under physiological conditions $(\mathrm{pH}=7.4)$. In addition, it maintained anti-staphylococcal activity due to in vitro FtsZ inhibition and showed $73 \%$ oral bioavailability. In vivo studies demonstrated that the prodrug was effective in a murine model of peritonitis with systematic infection with methicillin-susceptible Staphylococcus aureus (MSSA, survival of 100\%) and methicillin-resistant Staphylococcus aureus (MRSA, survival of 67\%), while the parent drug was not effective in this model [73].

The second prodrug TXY541 (42, Figure 16) is a carboxamide derivative with increased solubility in water (143-fold in citrate solution). Interestingly, the solubility in PBS decreased, to almost half the solubility of the parental compound. The stability study revealed that TXY541 is stable in citrate solution and is converted under physiological conditions to PC190723, but at slower rates than the parental compound is $\mathbf{4 1}$. In mouse serum, the conversion occurred faster, which suggest an enzymatic conversion. The oral bioavailability of the prodrug 42 was $29.6 \%$, and in vivo evaluation showed that this analog was effective against systematic infection with MSSA (83\% survival) and MRSA (100\% survival) [74].

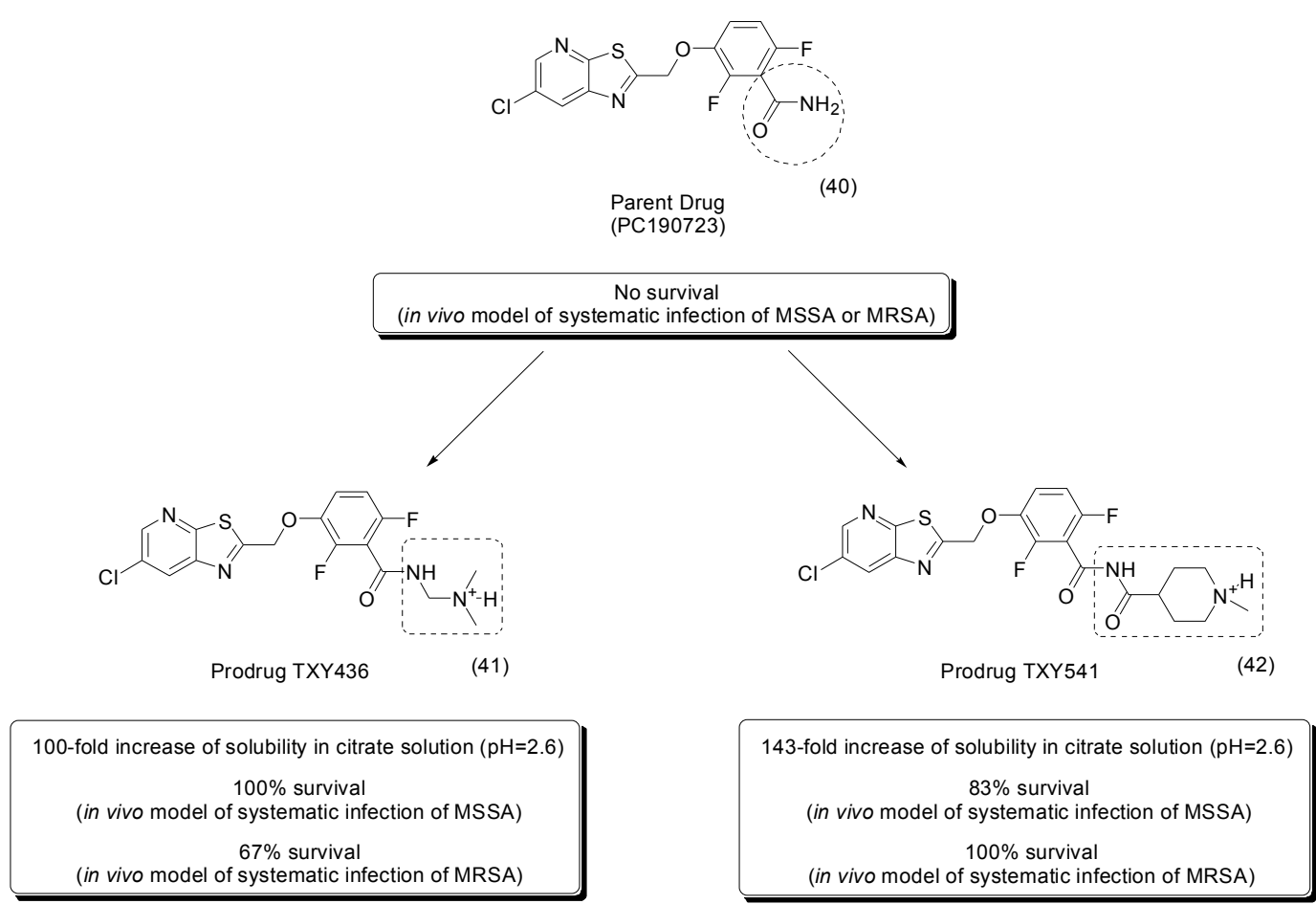

Figure 16. Benzamide and carboxamide prodrugs of PC190723 [73,74].

\section{Carbamate Prodrugs}

The benzamide compound CI-994 (43) is a potent inhibitor of histone deacetylases (HDACs). HDACs have an essential role in the regulation of gene expression, and several types of inhibitors exhibit antitumor activity [75,76], although adverse effects and poor solubility in water limit its use. Two glucuronide prodrugs, one (compound 44) linked to the glucuronide moiety by a spacer and the other linked directly by a carbamate group (compound 45), were used to resolve these limitations 
(Figure 17). While the solubility of CI-994 is $0.08 \mathrm{mg} / \mathrm{mL}$, those of the prodrugs were greater than $1 \mathrm{mg} / \mathrm{mL}$. Both compounds were stable at different $\mathrm{pH}$ values (2.1 and 7.0). In addition, the prodrugs were evaluated in vitro using an antiproliferative assay with NCI-H661 non-small cell lung cancer cells. The results demonstrated that this compound, when incubated with $\beta$-glucuronidase, showed the same antiproliferative activity $\left(\mathrm{IC}_{50}=20 \mu \mathrm{M}\right)$ shown by $\mathrm{CI}-994$. Without the enzyme, the prodrugs had decreased cytotoxicity, which may decrease the toxic effects of the parent drug [77].

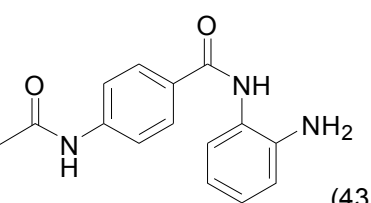

(43)

Parent drug Cl-994

Water solubility $=0.08 \mathrm{mg} / \mathrm{mL}$

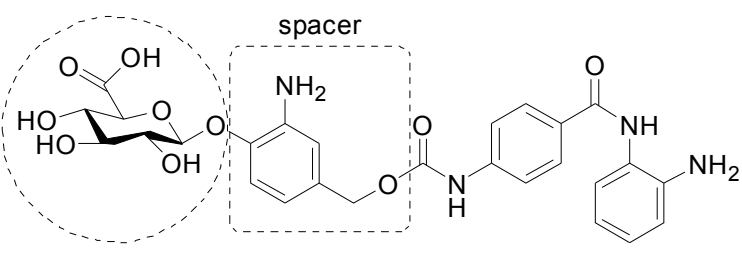

Water solubility $>1 \mathrm{mg} / \mathrm{mL}$

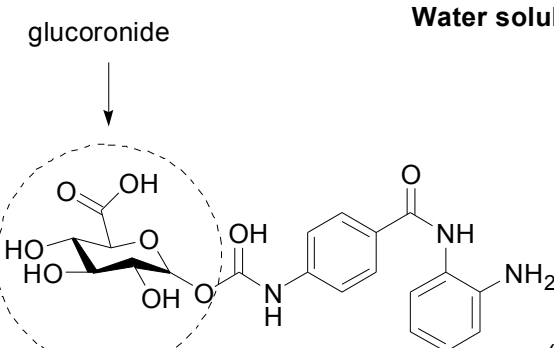

(45)

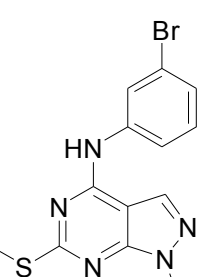

Water solubility $=0.01 \mathrm{mg} / \mathrm{mL}$

Membrane permeability $=2.11 \times 10^{-6} \mathrm{~cm} \mathrm{~s}^{-1}$
Water solubility $=6 \mathrm{mg} / \mathrm{mL}$

Membrane permeability $=0.01 \times 10^{-6} \mathrm{~cm} \mathrm{~s}^{-1}$

Figure 17. Glucuronide and pyrazolo[3,4-d]pyrimides prodrugs $[77,78]$.

Pyrazolo[3,4- $d$ ]pyrimides compounds are able to inhibit oncogenic tyrosine kinases and may be used to treat cancer. In general, pyrazolo[3,4-d]pyrimides compounds have low solubility in water [79]. Prodrugs of pyrazolo[3,4-d]pyrimidine compounds were designed to enhance its pharmacokinetic properties using a water-soluble $N$-methylpiperazino promoiety linked by a $O$-alkyl carbamate linker. The prodrug 47 showed 600-fold improvement in solubility compared to the parent drug 46 (Figure 17). In vitro assay showed good increase in passive membrane permeability, from $0.01 \times 10^{-6} \mathrm{~cm} \cdot \mathrm{s}^{-1}$ to $2.11 \times 10^{-6} \mathrm{~cm} \cdot \mathrm{s}^{-1}$. In addition, this compound was more cytotoxic compared to the parental drug; however, the mechanism of action is still not well characterized [78].

Photodynamic therapy is a non-invasive treatment for several types of cancer and infectious diseases [80]. This strategy consists in administration of a sensitizer and non-mutagenic substance 
that will be irradiated only in the affected area, where it will be activated by a specific wavelength of light [81]. This tool can be considered a prodrug approach, in that it uses the light to convert the photosensitizer (prodrug) to an active compound and in that both the selectivity and the solubility of the photosensitizer are important in design [80].

Three photopaclitaxel prodrugs were generated by linking paclitaxel (17) with a coumarinic derivative. The most soluble compound 48 showed at least 400,000-fold higher solubility in water compared to paclitaxel (Figure 18). This same compound was stable under physiological and storage conditions. In a photoconversion assay, the carbamate prodrug 48 rapidly generated paclitaxel with minimal tissue damage under $365 \mathrm{~nm}$ UV-A light irradiation at low power [82].

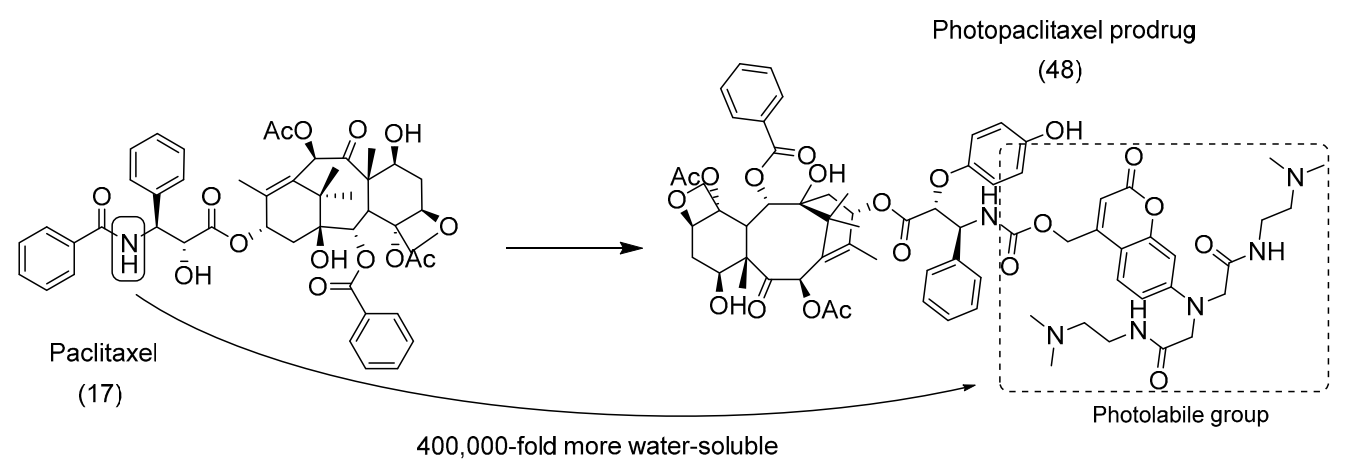

Figure 18. Photopaclitaxel prodrug [82].

\section{Carbonate Prodrugs}

In an attempt to improve the solubility of an anticancer compound, CHS8281 (49), a series of prodrugs was synthesized using a carbonate group to link a tetraethylene-glycol moiety to the parental drug. The prodrug EB1627 (50) was 600-fold more soluble than the parental drug at pH 5.5 (Figure 19). The selection of the carbonate group provided the required hydrolytic labiality and rapid release of the active drug in vivo [83].<smiles>CNC(=NN)Nc1ccncc1</smiles>

CHS8281

Solubility: $0.5 \mu \mathrm{g} / \mathrm{mL}$ at $\mathrm{pH} 7.4$ $2.0 \mu \mathrm{g} / \mathrm{mL}$ at $\mathrm{pH} 5.5$

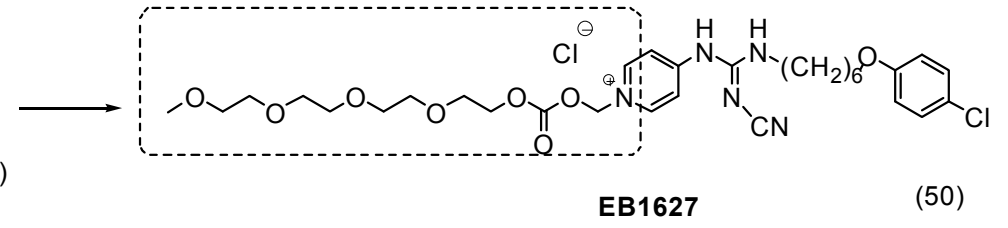

Solubility: $120 \mu \mathrm{g} / \mathrm{mL}$ at $\mathrm{pH} 7.4$ $>1200 \mu \mathrm{g} / \mathrm{mL}$ at $\mathrm{pH} 5.5$

Figure 19. CHS8281 prodrug [83].

To overcome the poor solubility of paclitaxel (17) and release the drug selectively into malignant tissue, an N-(2-hydroxypropyl)-methacrylamide (HPMA) copolymer-drug conjugate 51 with an $\mathrm{AB}_{3}$ self-immolative dendritic linker was designed. The HPMA was used as a water-soluble group, and the dendritic peptide linked the HPMA to the parent drug (Figure 20). This enzyme-cleavable linker served as a platform with a triple payload of paclitaxel attached by a carbonate group [84]. Interestingly, HPMA not only showed improved solubility but also selectively accumulated in tumors due to its enhanced permeability and retention [85]. 


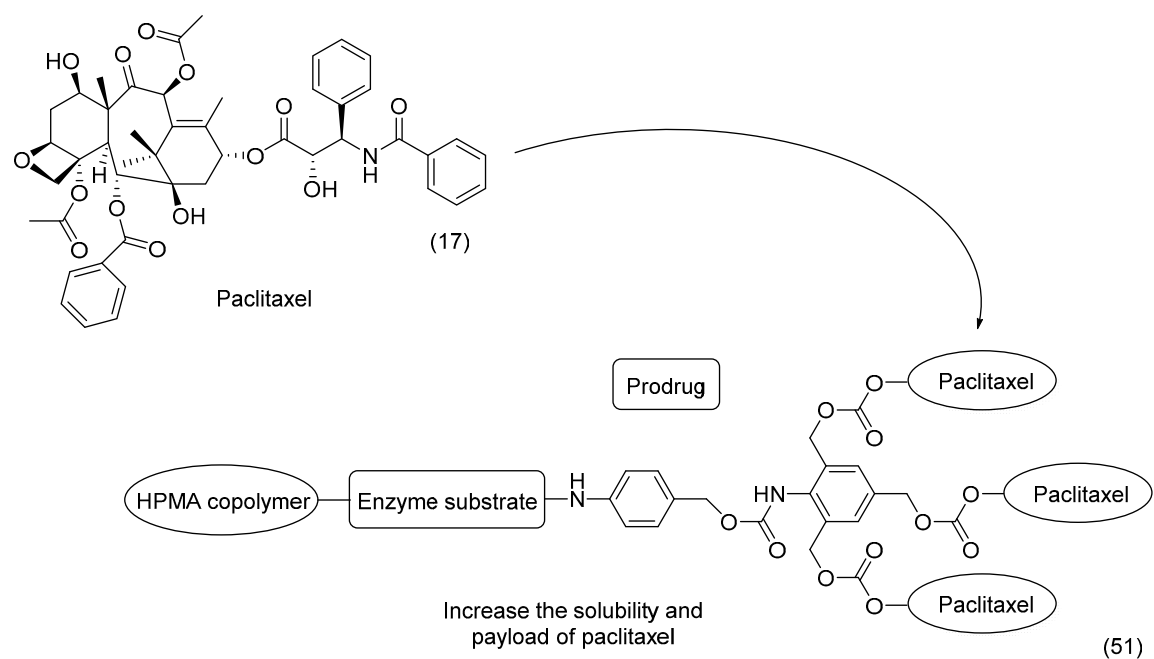

Figure 20. Copolymer-paclitaxel conjugate [84].

\section{Ether Prodrugs}

A glucuronide prodrug of the anticancer compound 10-hydroxycamptothecin (52) was reported by Leu et al. The authors used the prodrug approach to improve the solubility of the parental drug, which showed anticancer activity against various cancer cell lines $[86,87]$. To improve the solubility of 10-hydroxycamptothecin, a prodrug was designed using glucuronic acid as a water-soluble moiety linked by a 3-nitrobenzyl spacer. The compound $\mathbf{5 3}$ was 80 -fold more soluble than the parental drug. The prodrug was activated by enzymatic cleavage followed by a 1,6-elimination reaction to release the parental drug (Figure 21) [88].

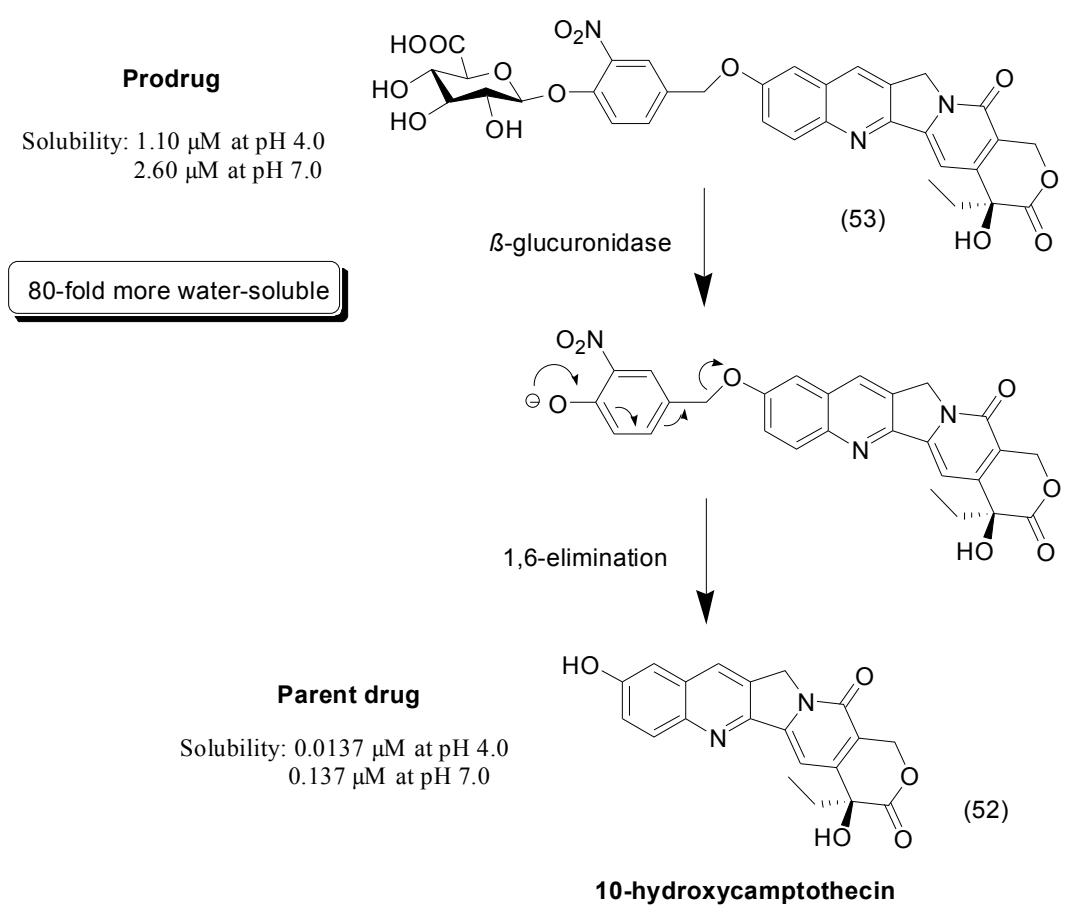

Figure 21. Prodrug release based on an enzymatic cleavage followed by a 1,6-elimination reaction [88].

Cadalene (54) is a flavonoid isolated from Zelkova serrata Makino. This molecule has a wide range of biological activities, including anticancer activities; however, its low solubility in water is a drawback [89]. Glycosylated cadalene derivatives linked by ether orethoxy spacers were synthesized as 
prodrugs. Prodrug 55 (Figure 22) exhibited the best solubility profile. In vivo, treatment with cadalene did not affect tumor volume, but treatment with the glycosylated prodrug reduced tumor volume by $50 \%$ compared to the control group. The authors hypothesized that the better activity of the prodrug could be due to its better solubility compared to cadalene [90].

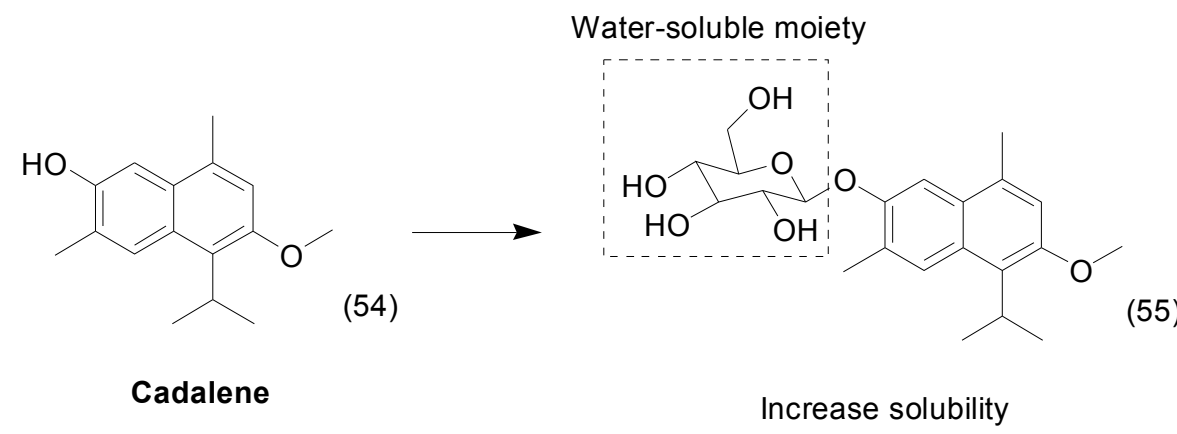

Figure 22. Cadalene prodrug with improved solubility in water [90].

\section{Imine Prodrugs}

Amphotericin B and nystatin prodrugs containing the pyridoxal phosphate as a water-soluble moiety were synthesized and evaluated. An imine group was used to allow the attachment of both subunits, and high water-soluble prodrugs 56 and 57 with solubilities up to $100 \mathrm{mg} / \mathrm{mL}$ were characterized (Figure 23) [91].

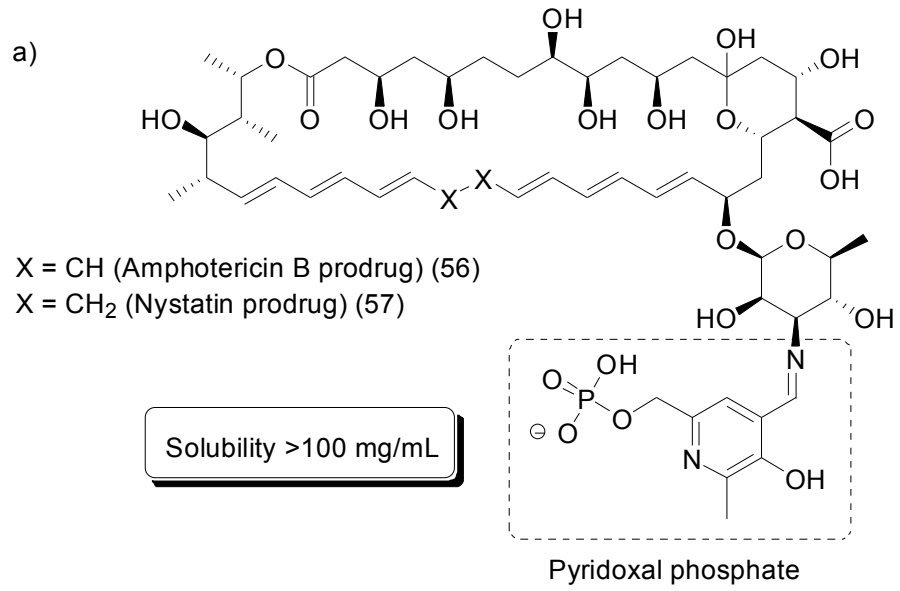

b)

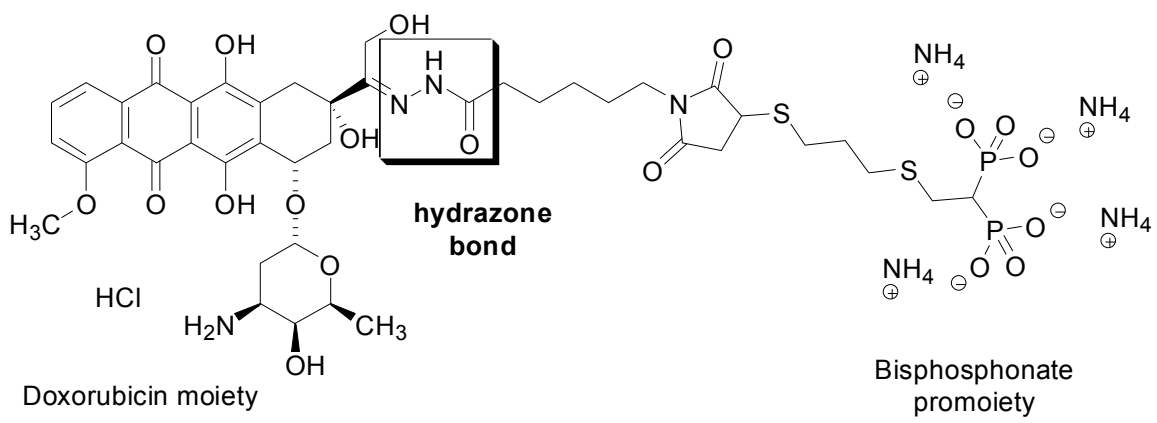

Increase solubility and stability in human plasma

Figure 23. (a) Amphotericin B and nystatin prodrugs; (b) Bisphosphonate doxorubicin prodrug [91,92]. 
Another paper described the synthesis of a novel bisphosphonate doxorubicin prodrug to treat bone metastases. To improve the solubility of doxorubicin, the water-soluble group bisphosphonate was attached to the parental drug by a hydrazone acid-sensitive bond. Moreover, the bisphosphonate moiety acts as a bone-targeting ligand, improving the drug's selectivity. The prodrug 58 showed considerably higher stability at $\mathrm{pH} 7.4$, with approximately $12 \%$ of the doxorubicin being released after $18 \mathrm{~h}$ of incubation (Figure 23) [92].

Synthesis of a soluble paclitaxel prodrug using an acid-sensitive hydrazone bond was reported by Moktan et al. The authors used a biopolymer elastin-like polypeptide (ELP) as a water-soluble group to improve the solubility of paclitaxel. ELP also enables thermal targeted delivery of paclitaxel, as hyperthermia above a specific transition temperature at the site of a tumor causes ELP to aggregate and accumulate, thus increasing the local concentration of the drug. The ELP paclitaxel prodrug 59 was able to increase solubility and cytotoxicity against a paclitaxel-resistant breast cancer cell line (Figure 24) [93].

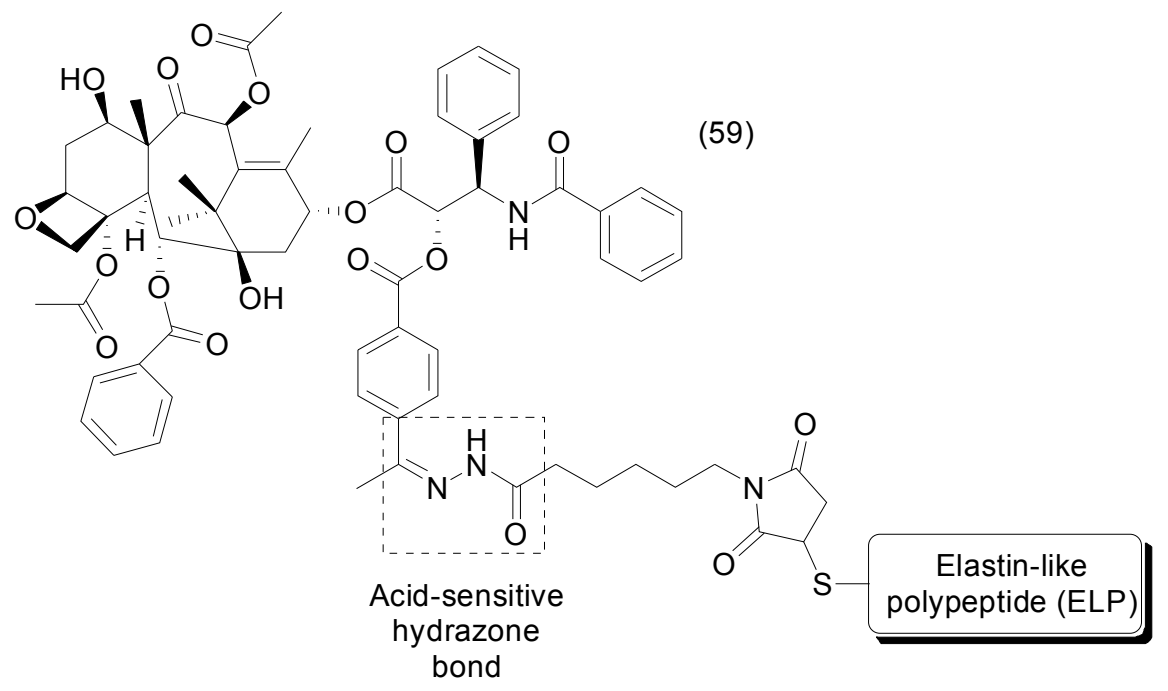

Figure 24. Paclitaxel-biopolymer-conjugated prodrug [93].

\section{Phosphate Prodrugs}

Phosphate ester compounds are relatively stable when free in metabolic surroundings because they have a low $\mathrm{pKa}$, between 1 and 2 . At a physiological $\mathrm{pH}$ of 7.0-7.4, the compounds are permanently deprotonated and therefore negatively charged but are readily activated upon complexation to various counterions in an enzyme's active site [94,95]. Intestinal alkaline phosphatases play an important role in drug metabolism by cleaving phosphate prodrugs and releasing the parental drugs [96]. Within the cell, the regeneration of the parental drug from the phosphate prodrug is difficult to determine. In most cases, this process is assumed to involve a specific enzyme or enzymes such as an esterase, an amidase, a phosphatase, or even a redox process $[95,97,98]$. Therefore, the phosphate-prodrug approach has been successfully used to enhance the solubility and bioavailability of the parental drug.

Degoey et al., synthesized a series of prodrugs of lopinavir (LPV, 60) and ritonavir (RTV, 61), HIV protease inhibitors. The oxymethylphosphate and oxyethylphosphate prodrugs (62/63 and 64/65, respectively) had more than 700 and 1600-fold enhanced solubility in water compared to LPV and RTV, respectively (Figure 25). Pharmacokinetic studies in rats and dogs showed high plasma levels of the parent drugs after administration via the oral route [99]. 


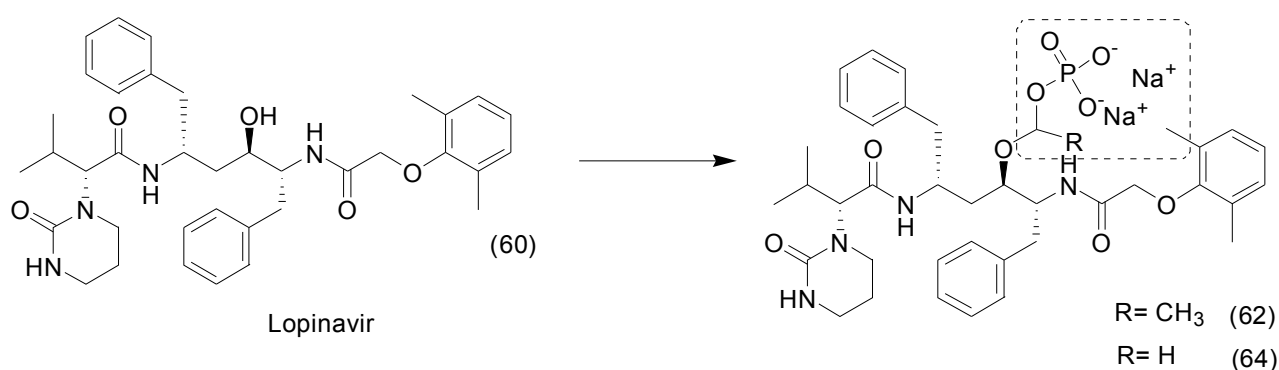

$>700$-fold more water soluble

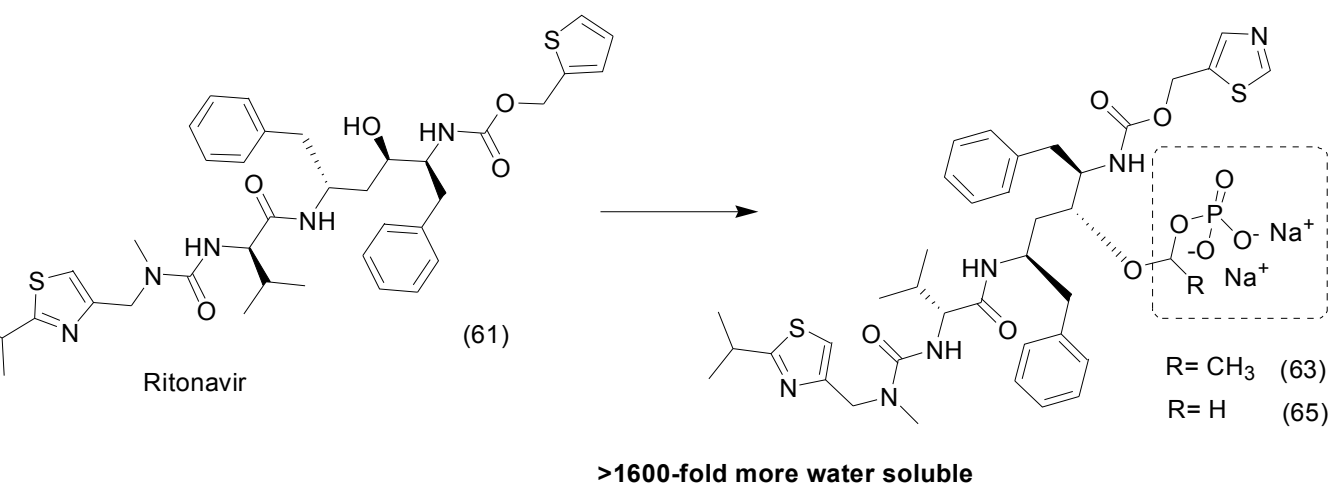

Figure 25. Structures of the prodrugs of lopinavir and ritonavir [99].

Another example of water soluble prodrug with phosphate group was synthesized by Flores-ramos et al., using as prototype the compound $\alpha$-6-chloro-2-(methylthio)-5-(naphthalen1-yloxy)- $1 H$-benzo[d]imidazole (66), a benzimidazole derivative. The solubility of the prodrug 67 was increased 50,000-fold when compared to its precursor by linking a disodium phosphate to the structure (Figure 26). In vitro and in vivo assays demonstrated that the prodrug have faciolicidal activity; however, administered dose in vivo was lower than the parent drug [100].

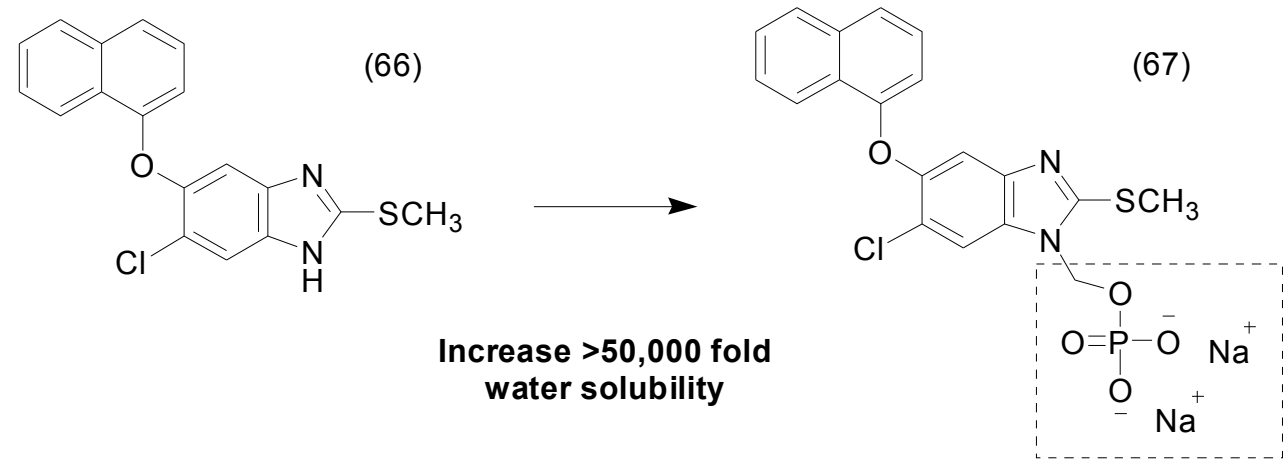

Figure 26. Benzimidazole phosphate prodrug [100].

The chalcone family is known to prevent CXCL12 chemokine from binding to its CXCR4 or CXCR7 receptors, preventing inflammatory reactions, but their poor solubility in water limits their use $(9 \mu \mathrm{M} / \mathrm{mL})$ [101]. To overcome this problem, chalcone prodrugs 68 were synthesized with different functional groups, such as phosphate, an L-seryl, and a sulfate. The phosphate prodrug 69 (Figure 27) showed a greater increase in solubility, to at least 3000 times greater solubility than the parent chalcone. These results allowed low-dose intranasal administration, with $\geqslant 50 \%$ inhibited eosinophil recruitment in the airways at a dose as low as $30 \mathrm{nmol} / \mathrm{kg}$ without any signs of toxicity [102]. 


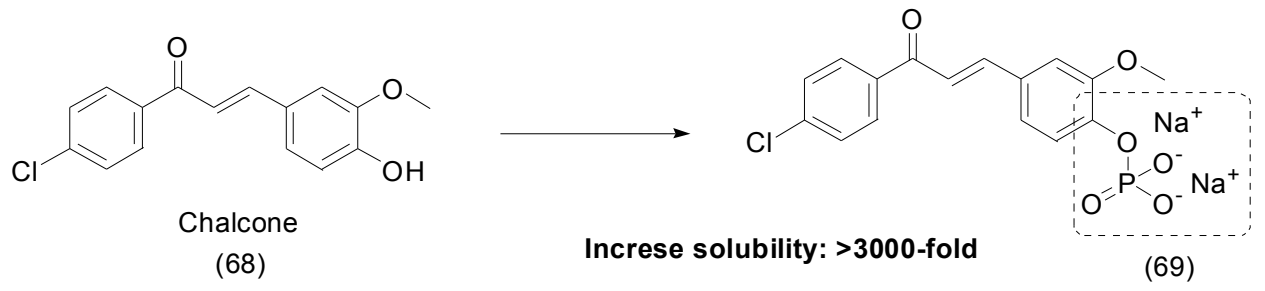

Figure 27. Chalcone-phosphate prodrugs [102].

Propofol (70) is another drug with high lipophilicity and is administered in an oil-in-water emulsion. To overcome this drawback, phosphate prodrugs of propofol have been generated using a phosphate group attached directly to the hydroxyl group of propofol with oxymethyl (compound 71) and ethylenedioxy moieties (compound 72) as spacers linked to a phosphate group (Figure 28). All these prodrugs demonstrated stability and enhanced solubility in water. Solubility of the ethyl dioxy phosphate derivative $\mathbf{7 2}$ was increased more than 70-fold compared to propofol. Furthermore, neither prodrug produced formaldehyde, a toxic subproduct, and thus both represent useful water-soluble prodrugs suitable for i.v. administration [103].

SB-3CT (73) is a selective inhibitor of matrix metalloproteinases 2 and 9 that is active in the treatment of traumatic brain injury (TBI) [63]. Its phosphate prodrug 74 (Figure 29) showed more than 2000 -fold enhanced solubility in water. The prodrug was readily hydrolyzed to the active $p$-hydroxy SB-3CT (75), which crossed the blood-brain barrier and reached a therapeutic concentration in the brain. In an in vivo assay in TBI mice, the prodrug significantly decreased brain-lesion volume and improved neurological outcomes [104].

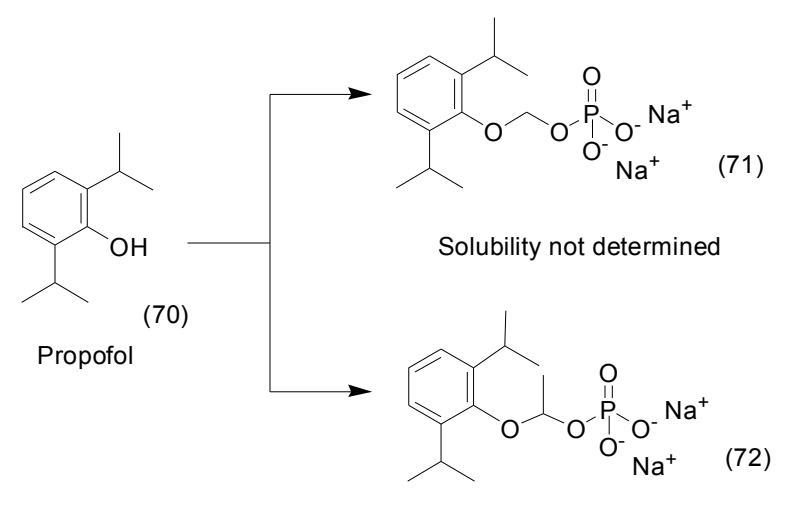

Figure 28. Propofol prodrug [103].

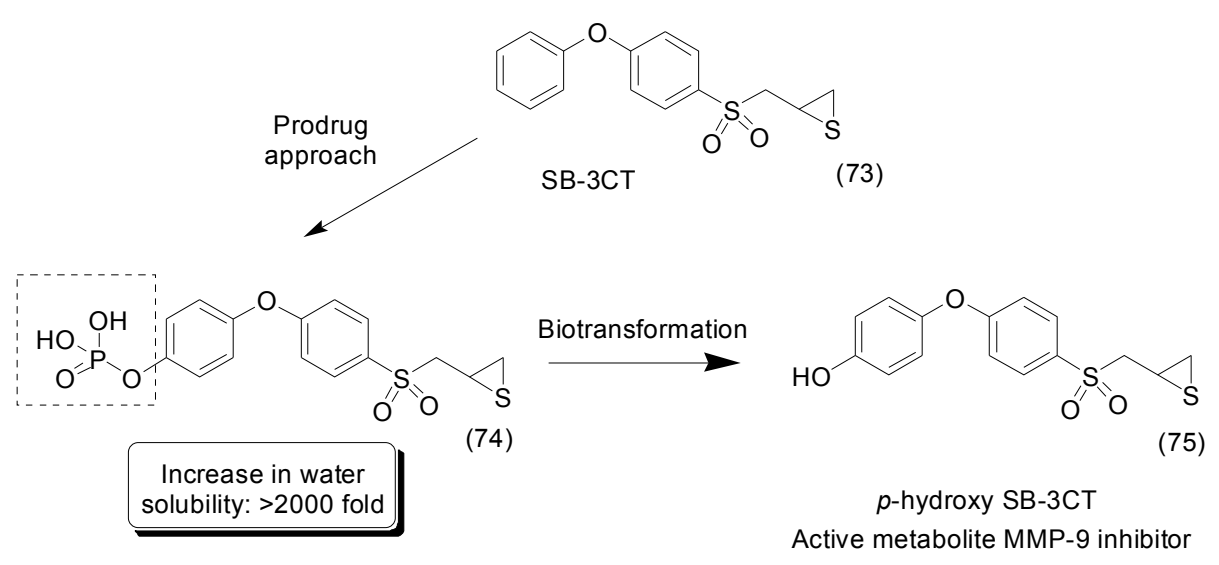

Figure 29. SB-3CT prodrug and its active metabolite [104]. 
Compound $\mathbf{7 6}$ is a benzimidazole derivative with antibacterial activity that inhibits DNA gyrase and topoisomerase IV [105,106]. Due to its poor solubility in water, Dowd et al., synthesized a benzimidazole phosphate-ester prodrug. The compound 77 was up to 30,000-fold more water soluble than the parent drug at physiological $\mathrm{pH}$ (Figure 30). Interestingly, the phosphate-ester prodrug was much less potent in vitro against all bacteria strains tested. Nevertheless, in the target-level assay, the prodrug exhibited similar activity to the parent drug against $S$. aureus gyrase and topoisomerase IV [107].

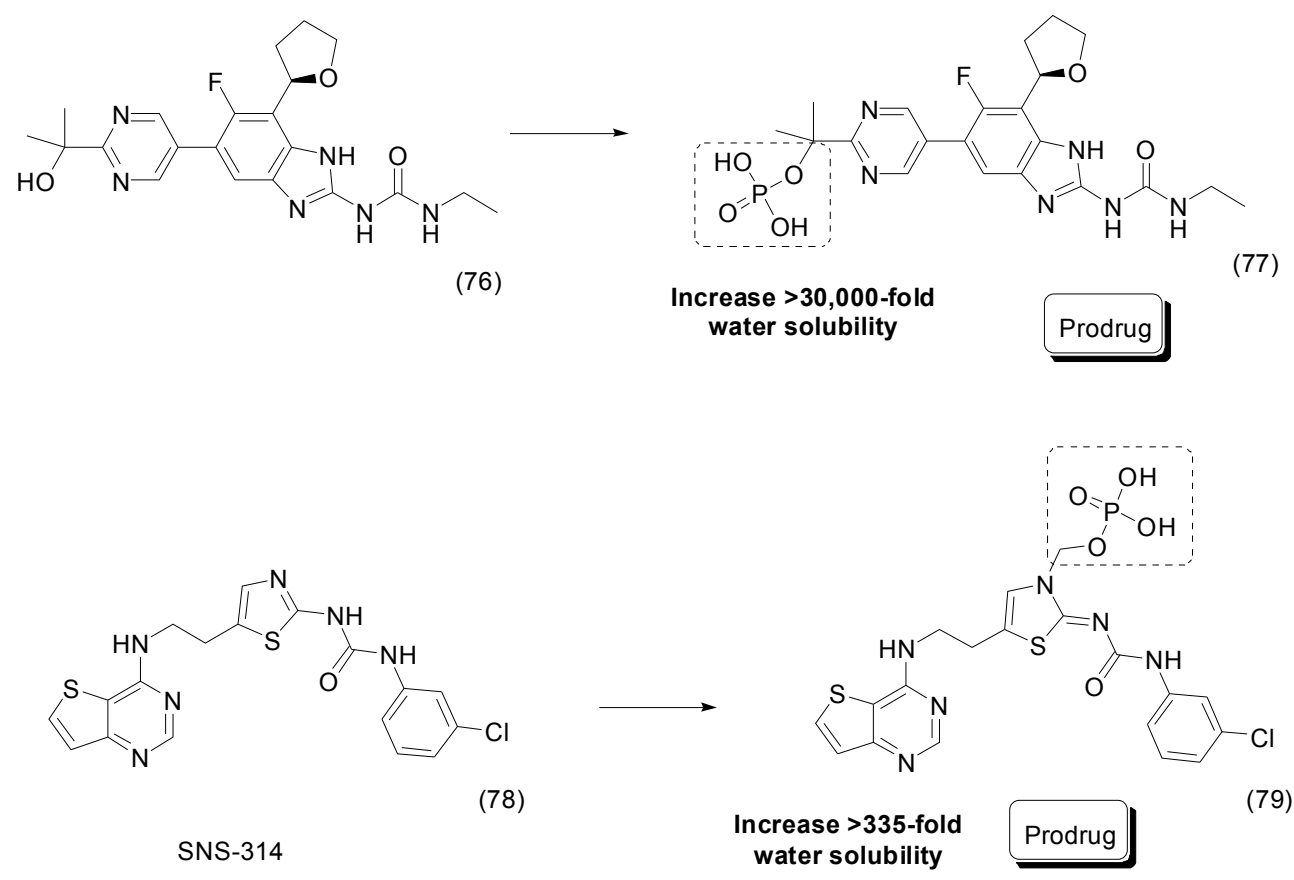

Figure 30. Benzimidazole and SNS-314 phosphate prodrugs $[107,108]$.

Aurora serine/threonine kinases have been described as a promising anti-cancer target [109]. To overcome the poor solubility in water of SNS-314 (78), an aurora kinase inhibitor, a prodrug was designed with several moieties attached to the parent drug, such as acyl-oxymethylene, amine-containing acyl-oxymethylene and phosphate group. Prodrug $\mathbf{7 9}$, a phosphate-ester derivative, was 335-fold more water soluble than the parent drug (Figure 30). Moreover, although the acyl-oxymethylene derivatives showed increased solubility (8-20-fold), they were much less effective than the phosphate-ester prodrug [108].

\section{Other Chemical Prodrugs}

Carbamazepine (CBZ) (80) is an effective anticonvulsant drug that causes less sedation and cognitive impairment than other anticonvulsants; however, its aqueous solubility is $120 \mu \mathrm{g} / \mathrm{mL}$, hindering intravenous administration [110]. To overcome this problem, CBZ prodrugs 81 and 82 with improved solubility were synthesized (Figure 31). The aqueous chemical stability of $\mathbf{8 1}$ was superior to that of 82. Compound $\mathbf{8 1}$ was dissolved in water, with apparent solubility in excess of $100 \mathrm{mg} / \mathrm{mL}$ (final $\mathrm{pH}$ value of 2.6). An in vivo pharmacokinetic assay with i.v. administration demonstrated that compound 81 was rapidly converted to CBZ [111]. 
<smiles>NCCSCC(=O)N1c2ccccc2C=Cc2ccccc21</smiles>

Solubility: $100,000 \mu \mathrm{g} / \mathrm{mL}$
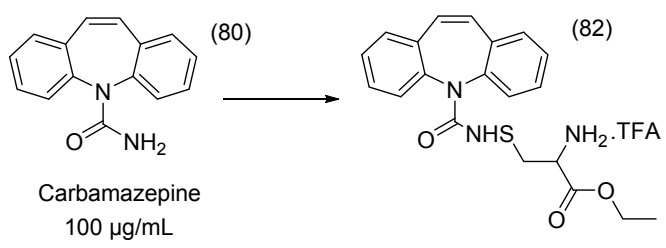

Solubility: not determined

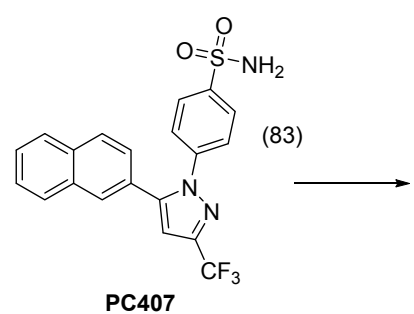

Solubilty: $1.6 \mu \mathrm{g} / \mathrm{mL}$

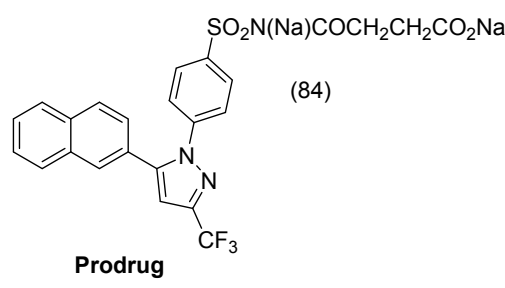

Solubilty: $20,300 \mu \mathrm{g} / \mathrm{mL}$

Figure 31. Carbamazepine and PC407 prodrugs [111,112].

The sulfonamide group was also utilized to develop a cyclooxygenase 2 (COX-2)-inhibitor prodrug of PC407 (83) for parenteral administration (Figure 31). The prodrug showed highly improved solubility, from $1.6 \mu \mathrm{g} / \mathrm{mL}$ to $20.3 \mathrm{mg} / \mathrm{mL}$. Prodrug 84 showed analgesic activity in vivo and aqueous stability and is a promising candidate COX-2 inhibitor for injectable formulation [112].

Tetrahydrocurcumin (THCur) (85) is a metabolite of curcumin that shows antioxidant and anticancer activities [113-115]. A series of THCur prodrugs was synthesized using carboxymethylcellulose (CMC) as a water-soluble group linked by an azo bond. 4-Amino-THCur (86, Figure 32) has shown increased solubility in water up to $5 \mathrm{mg} / \mathrm{mL}$ and was released in the colon via azoreductase enzymes of colonic bacteria (up to $62 \%$ within $24 \mathrm{~h}$ ). In human colon adenocarcinoma cell lines (HT-29), the prodrug was cytotoxic, with a $\mathrm{IC}_{50}$ of $28.67 \pm 1.01 \mu \mathrm{g} / \mathrm{mL}$, and selective to these cells, unlike curcumin, which was non-selective [116].

Famotidine (87) is a histamine H2-receptor blocker used to treat and prevent ulcers [117]. Vijayaraj et al., synthesized a water-soluble prodrug of famotidine by introducing a sulphoxide group. This modification (compound 88) increased solubility in water 6.7-fold compared to famotidine (Figure 32). The prodrug was stable at pH 1.2 and 7.4 and might be effective in ulcer therapy [118].

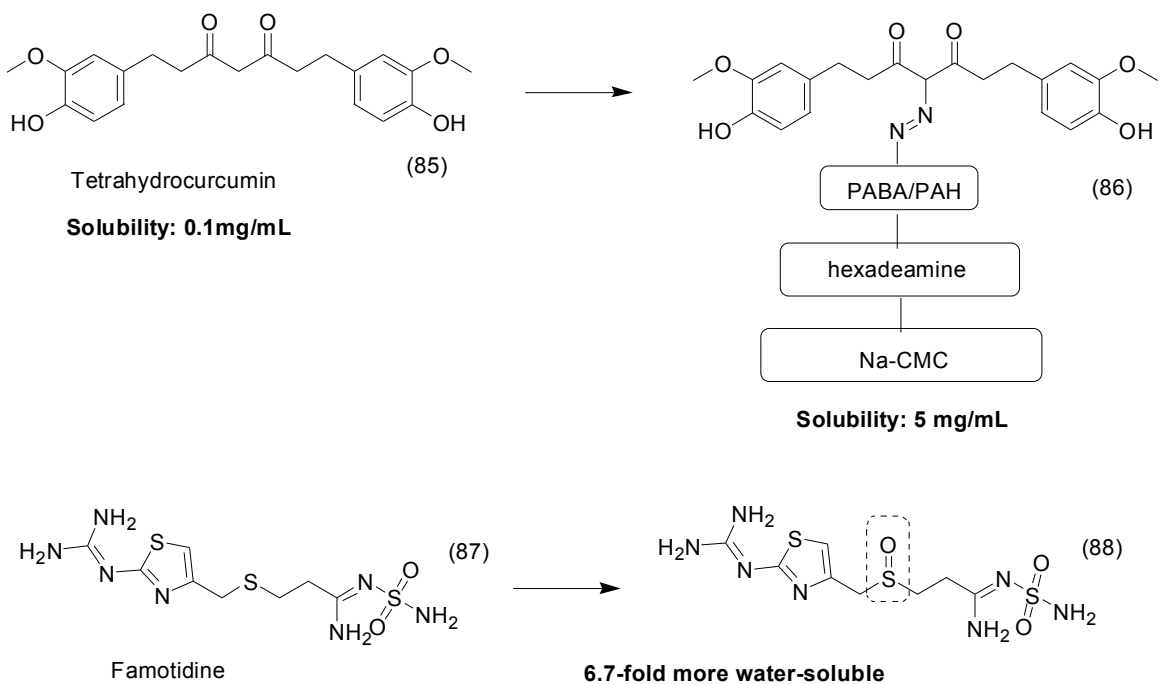

Figure 32. Tetrahydrocurcumin and famotidine prodrugs [116,118]. 


\section{Marketed Prodrugs}

From 2005 to 2015, several prodrugs were discovered and launched in the market (Table 3). Some of these drugs are summarized in Table 3 and will be discussed below.

Table 1. Prodrugs launched in the USA, 2005-2015 a

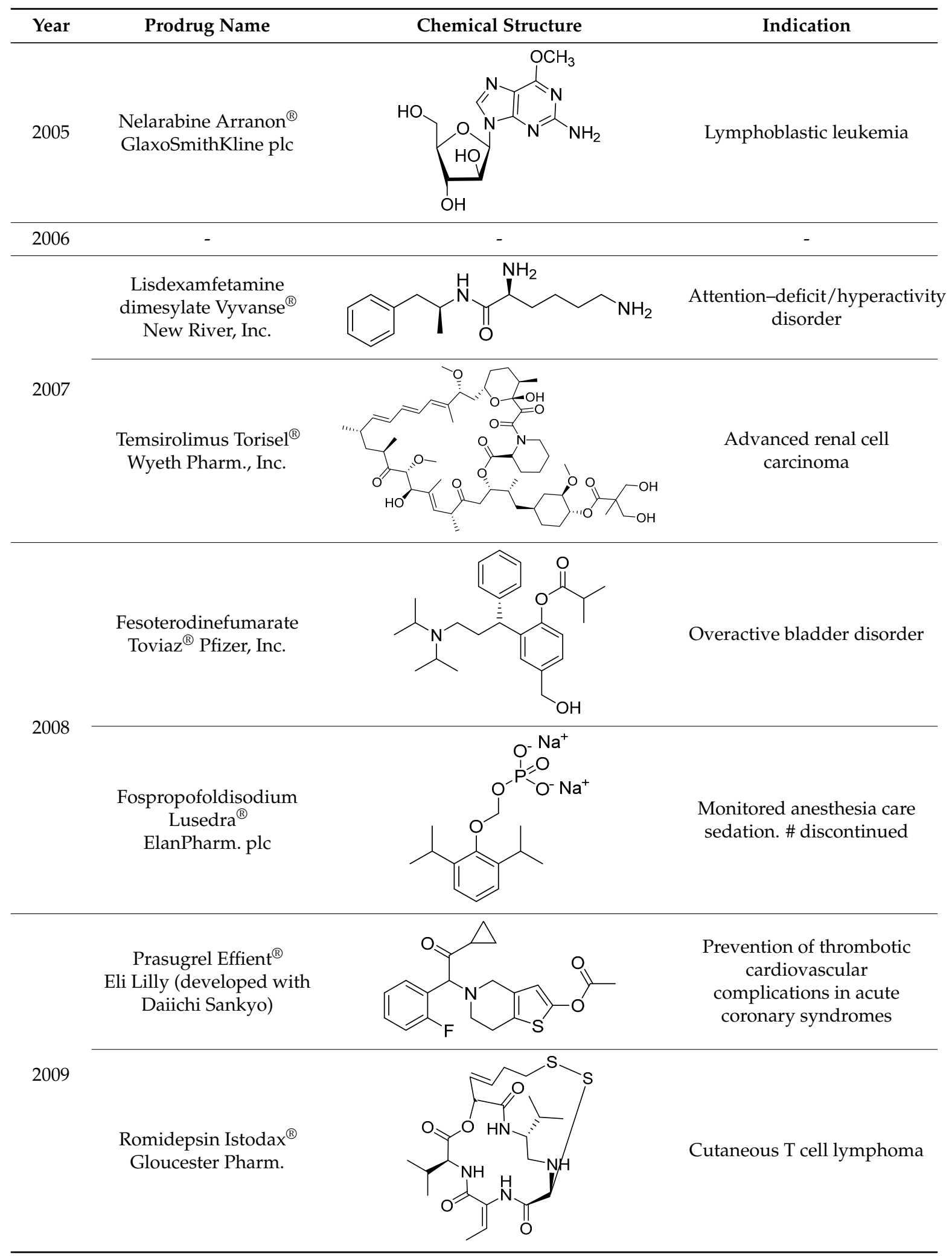


Table 2. Cont.

\begin{tabular}{|c|c|c|c|}
\hline Year & Prodrug Name & Chemical Structure & Indication \\
\hline \multirow{3}{*}{2010} & $\begin{array}{l}\text { Dabigatranetexilate } \\
\text { mesylate Pradaxa } \\
\text { Boehringer } \\
\text { Ingelheim GmbH }\end{array}$ & & $\begin{array}{l}\text { Thromboembolism acute } \\
\text { coronary syndrome }\end{array}$ \\
\hline & $\begin{array}{c}\text { Fingolimod Gilenya }{ }^{\circledR} \\
\text { Novartis } \\
\text { International AG }\end{array}$ & & $\begin{array}{c}\text { Multiple sclerosis } \\
\text { [sphingosin-1-phosphate } \\
\text { (S1P) agonist with } \\
\text { cannabinoid antagonist] }\end{array}$ \\
\hline & $\begin{array}{l}\text { Ceftarolinefosamil } \\
\text { Teflaro }{ }^{\circledR} \text { Forest } \\
\text { Laboratories, Inc. }\end{array}$ & & Bacterial skin infection \\
\hline \multirow{3}{*}{2011} & $\begin{array}{l}\text { Abiraterone acetate } \\
\text { Zytiga }^{\circledR} \\
\text { Janssen Biotech, Inc. }\end{array}$ & & $\begin{array}{c}\text { Hormone-refractory prostate } \\
\text { cancer } \\
\text { (17- } \alpha \text {-hydrolase } / \mathrm{C} 17,20 \text { lyase })\end{array}$ \\
\hline & $\begin{array}{l}\text { Azilsartanmedoxomil } \\
\text { Edarbi }^{\circledR} \text { Takeda Pharm. }\end{array}$ & & $\begin{array}{c}\text { Hypertension } \\
\text { (angiotensin II antagonist) }\end{array}$ \\
\hline & $\begin{array}{l}\text { Gabapentin encarbil } \\
\text { Horizant }{ }^{\circledR} \\
\text { GlaxoSmithKline plc }\end{array}$ & & $\begin{array}{l}\text { Restless leg syndrome } \\
\text { (GABA and Ca channel } \\
\text { modulator) new indication }\end{array}$ \\
\hline 2012 & $\begin{array}{l}\text { Tafluprost Zioptan } \\
\text { Merck \& Co., Inc. }\end{array}$ & & $\begin{array}{c}\text { Elevated intraocular } \\
\text { pressure } \\
\text { (prostaglandin analog) }\end{array}$ \\
\hline
\end{tabular}


Table 3. Cont.

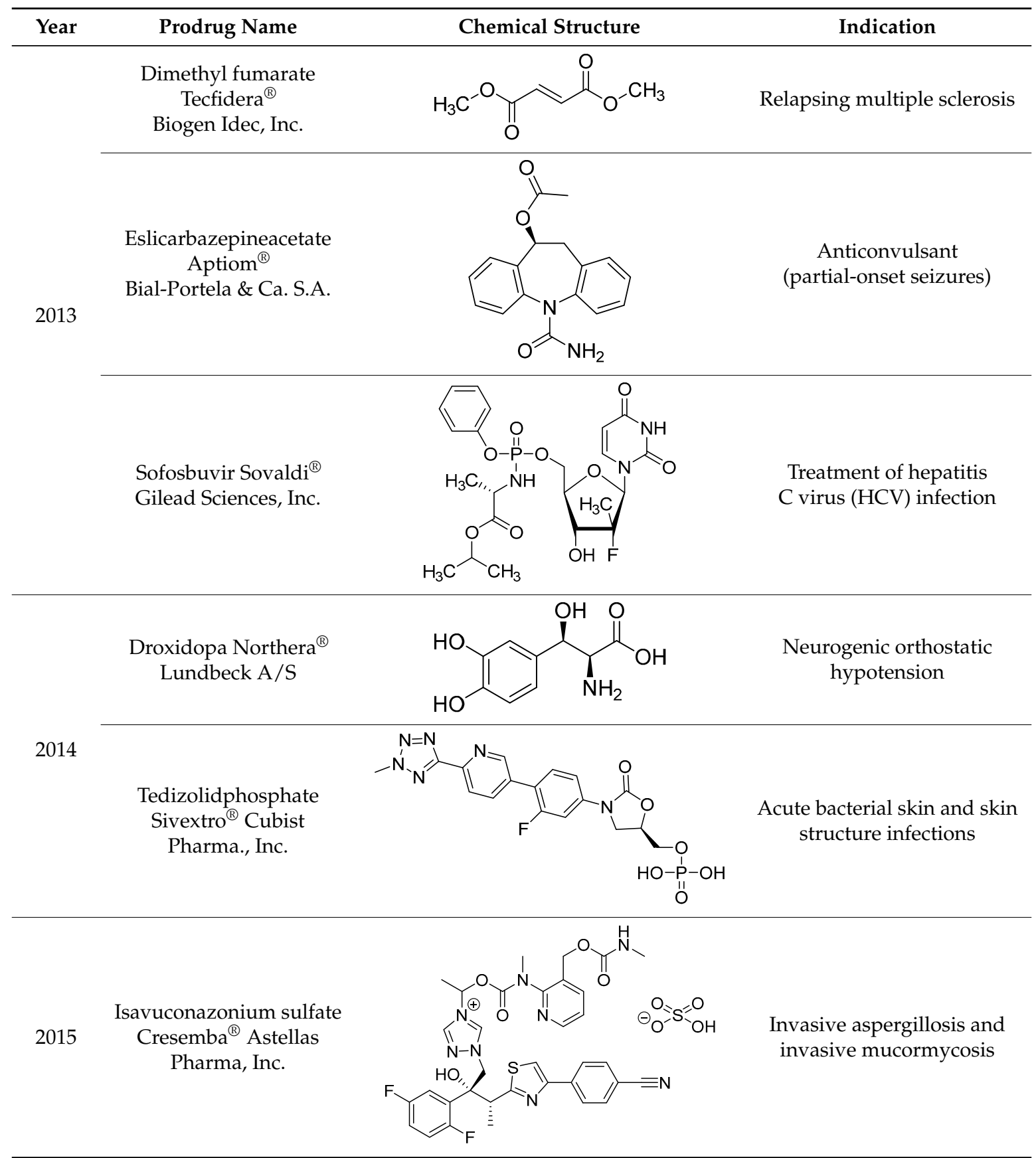

${ }^{\text {a }}$ The table does not include the launch of reformulations or new indications of already-marketed prodrugs. Drugs approved till the first half 2015.

Eslicarbazepine (ESL) is an antiepileptic prodrug developed from oxcarbazepine and approved by the European Medicines Agency (EMA), the Food and Drug Administration and Health Canada as an adjunctive therapy in adults with partial-onset seizures. The development of the ESL acetate prodrug was based on the observation that the active $S$-enantiomer of ESL is produced after biotransformation at a rate 20 -fold higher than the inactive $R$-enantiomer $[119,120]$.

Fospropofol disodium, a phosphate ester prodrug of propofol, was approved by the FDA in 2008 as a sedative-hypnotic agent for monitored anesthesia-care sedation in patients who are undergoing diagnostic or therapeutic procedures. The aqueous solubility of fospropofol provides an advantage over propofol, which is available only as a lipid-containing oil-water emulsion. These advantages 
include lack of pain on injection, different pharmacokinetic profile due to in vivo conversion of fospropofol to propofol and rapid recovery from sedation [121,122].

Ceftaroline fosamil, a phosphoramidate prodrug launched in 2011 for the treatment of bacterial skin infections and bacterial pneumonia, showed 50-fold enhancement of solubility relative to the parental drug, thus enabling formulation of a marketable injectable solution [123].

Tedizolid phosphate, which has been marketed for the treatment of acute bacterial skin and skin-structure infections since 2014, is a phosphate-ester prodrug of the active compound tedizolid. The additional phosphate group provides improved aqueous solubility and thus bioavailability [124,125].

\section{Conclusions}

The prodrug approach has been a successful tool for improving solubility in water, as can be observed from several publications that showed up to 400,000 -fold increased solubility compared to the parent drug, as described herein. This approach can make it possible to avoid discarding promising active prototypes or drugs with therapeutic uses limited by poor solubility. The rational selection of the adequate pro-moiety and the type of linkage, (e.g., ester, amide, carbamate and phosphate), may determine the prodrug selectivity, toxicity, and ideal bioconversion profile.

Furthermore, the prodrug approach could be viewed as an alternative in the early phases of drug discovery. This technique may be used to modulate pharmacokinetic properties (absorption, distribution, metabolism and excretion), as well as poor water solubility, a critical step in pre-clinical phases. The majority of prodrugs presented herein were esters and amides because esterases and amidases could activate them, releasing the parent drug. Amino acids were the most-used water-soluble pro-moieties and, as demonstrated by several reviewed authors, efficiently increase solubility in water. Nevertheless, several other chemical groups are represented herein to a lesser degree, such as glycol groups (e.g., polyethylene glycol and ethylene glycol) and glycosides.

Several prodrugs were approved in the last 10 years by the FDA, although not all prodrugs were designed to increase solubility. Nevertheless, many prodrugs were designed for this purpose, such as tedizolid phosphate, ceftaroline fosamil and fospropofol disodium. Therefore, the prodrug approach is an important tool in rational drug design to improve drug solubility in water.

Acknowledgments: The authors thank the Programa de Apoio ao Desenvolvimento Científico da Faculdade de Ciências Farmacêuticas da UNESP (PADC-FCF UNESP) and Fundação de Amparo à Pesquisa do Estado de São Paulo (FAPESP 2014/02240-1; 2014/24811-0; 2014/06755-6 and 2014/14980-0) for financial support.

Author Contributions: Authors D.H.J., G.F.S.F., D.E.C., T.R.F.M. and C.M.C. designed the study, analyzed and organized the literature papers. J.L.S. and C.M.C. helped rewrite the revised manuscript; J.L.S. and C.M.C. revised the manuscript and approved it in its final form. All authors edited and contributed to drafts of the manuscript. All authors approved the final form of the manuscript.

Conflicts of Interest: The authors declare no conflict of interest.

\section{References}

1. Rautio, J.; Kumpulainen, H.; Heimbach, T.; Oliyai, R.; Oh, D.; Järvinen, T.; Savolainen, J. Prodrugs: Design and clinical applications. Nat. Rev. Drug Discov. 2008, 7, 255-270. [CrossRef] [PubMed]

2. Takagi, T.; Ramachandran, C.; Bermejo, M.; Yamashita, S.; Yu, L.X.; Amidon, G.L. A provisional biopharmaceutical classification of the top 200 oral drug products in the United States, Great Britain, Spain, and Japan. Mol. Pharm. 2006, 3, 631-643. [CrossRef] [PubMed]

3. Huttunen, K.; Raunio, H.; Rautio, J. Prodrugs: Design and clinical applications. Pharmacol. Rev. 2011, 63, 750-771. [CrossRef] [PubMed]

4. Stella, V.J; Nti-Addae, K.W. Prodrug strategies to overcome poor water solubility. Adv. Drug Deliv. Rev. 2007, 59, 677-694. [CrossRef] [PubMed]

5. Abu-jaish, A.; Jumaa, S.; Karaman, R. Prodrug Overview. In Prodrugs Design: A New Era; Karaman, R., Ed.; Nova Publisher: Hauppauge, NY, USA, 2014; pp. 77-102. 
6. Beaumont, K.; Webster, R.; Gardner, I.; Dack, K. Design of ester prodrugs to enhance oral absorption of poorly permeable compounds: Challenges to the discovery scientist. Curr. Drug Metab. 2003, 4, 461-485. [CrossRef] [PubMed]

7. Testa, B. Prodrugs: Bridging pharmacodynamic/pharmacokinetic gaps. Curr. Opin. Chem. Biol. 2009, 13, 338-344. [CrossRef] [PubMed]

8. Chung, M.-C.; Silva, A.T.D.A.; Castro, L.F.; Güido, R.V.C.; Nassute, J.C.; Ferreira, E.I. Latenciação e formas avançadas de transporte de fármacos. Rev. Bras. Ciênc. Farm. 2005, 41, 155-180. [CrossRef]

9. Redasani, V.K.; Bari, S.B. Prodrug Design: Perspectives, Approaches and Applications in Medicinal Chemistry, 1st ed.; Academic Press: London, UK, 2015.

10. Zovko, M.; Zorc, B.; Novak, P.; Tepeš, P.; Cetina-Čižmek, B.; Horvat, M. Macromolecular prodrugs: XI. Synthesis and characterization of polymer-estradiol conjugate. Int. J. Pharm. 2004, 285, 35-41. [CrossRef] [PubMed]

11. Ettmayer, P.; Amidon, G.L.; Clement, B.; Testa, B. Lessons Learned from Marketed and Investigational Prodrugs. J. Med. Chem. 2004, 47, 2393-2404. [CrossRef] [PubMed]

12. Han, H.K.; Amidon, G.L. Targeted prodrug design to optimize drug delivery. AAPS PharmSci 2000, 2, E6. [CrossRef] [PubMed]

13. Silva, A.T.D.A.; Chung, M.C.; Castro, L.F.; Güido, R.V.C.; Ferreira, E.I. Advances in prodrug design. Mini Rev. Med. Chem. 2005, 5, 893-914. [CrossRef] [PubMed]

14. Williams, H.D.; Trevaskis, N.L.; Charman, S.A.; Shanker, R.M.; Charman, W.N.; Pouton, C.W.; Porter, C.J.H. Strategies to address low drug solubility in discovery and development. Pharmacol. Rev. 2013, 65, 315-499. [CrossRef] [PubMed]

15. Müller, C.E. Prodrug approaches for enhancing the bioavailability of drugs with low solubility. Chem. Biodivers. 2009, 6, 2071-2083. [CrossRef] [PubMed]

16. Wenlock, M.C.; Austin, R.P.; Barton, P.; Davis, A.M.; Leeson, P.D. A comparison of physiochemical property profiles of development and marketed oral drugs. J. Med. Chem. 2003, 46, 1250-1256. [CrossRef] [PubMed]

17. Chung, M.C.; Ferreira, E.I.; Leandro, J.; Giarolla, J.; Rando, D.G.; Almeida, A.E.; Bosquesi, P.L.; Menegon, R.F.; Blau, L. Prodrugs for the Treatment of Neglected Diseases. Molecules 2008, 616-677. [CrossRef]

18. Lee, S.; Kim, S.M.; Lee, R.T. Thioredoxin and Thioredoxin Target Proteins: From Molecular Mechanisms to Functional Significance. Antioxid. Redox Signal. 2013, 18, 1165-1207. [CrossRef] [PubMed]

19. Wipf, P.; Lynch, S.M.; Powis, G.; Birmingham, A.; Englund, E.E. Synthesis and biological activity of prodrug inhibitors of the thioredoxin-thioredoxin reductase system. Org. Biomol. Chem. 2005, 3, 3880-3882. [CrossRef] [PubMed]

20. Vollmann, K.; Qurishi, R.; Hockemeyer, J.; Müller, C.E. Synthesis and properties of a new water-soluble prodrug of the adenosine A 2A receptor antagonist MSX-2. Molecules 2008, 13, 348-359. [CrossRef] [PubMed]

21. De Lera Ruiz, M.; Lim, Y.; Zheng, J. Adenosine A2A receptor as a drug discovery target. J. Med. Chem. 2014, 57, 3623-3650. [CrossRef] [PubMed]

22. Burbiel, J.C.; Mu, C.E. Multigram-Scale Syntheses, Stability, and Photoreactions of A 2A Adenosine Receptor Antagonists with 8-Styrylxanthine Structure: Potential Drugs for Parkinson's Disease. J. Org. Chem. 2004, 69, 3308-3318.

23. Sauer, R.; Maurinsh, J.; Reith, U.; Fülle, F.; Klotz, K.N.; Müller, C.E. Water-soluble phosphate prodrugs of 1-propargyl-8-styrylxanthine derivatives, A2A-selective adenosine receptor antagonists. J. Med. Chem. 2000, 43, 440-448. [CrossRef] [PubMed]

24. McGuigan, C.; Balzarini, J. Aryl furano pyrimidines: The most potent and selective anti-VZV agents reported to date. Antiviral Res. 2006, 71, 149-153. [CrossRef] [PubMed]

25. Diez-Torrubia, A.; Balzarini, J.; Andrei, G.; Snoeck, R.; de Meester, I.; Camarasa, M.J.; Velázquez, S. Dipeptidyl peptidase IV dependent water-soluble prodrugs of highly lipophilic bicyclic nucleoside analogues. J. Med. Chem. 2011, 54, 1927-1942. [CrossRef] [PubMed]

26. Han, H.; de Vrueh, R.L.; Rhie, J.K.; Covitz, K.M.; Smith, P.L.; Lee, C.P.; Oh, D.M.; Sadée, W.; Amidon, G. 5'-Amino acid esters of antiviral nucleosides, acyclovir, and AZT are absorbed by the intestinal PEPT1 peptide transporter. Pharm. Res. 1988, 15, 1154-1159. [CrossRef] 
27. Ohwada, J.; Ozawa, S.; Kohchi, M.; Fukuda, H.; Murasaki, C.; Suda, H.; Murata, T.; Niizuma, S.; Tsukazaki, M.; Ori, K.; et al. Synthesis and biological activities of a pH-dependently activated water-soluble prodrug of a novel hexacyclic camptothecin analog. Bioorg. Med. Chem. Lett. 2009, 19, 2772-2776. [CrossRef] [PubMed]

28. Sugawara, M.; Huang, W.; Fei, Y.J.; Leibach, F.H.; Ganapathy, V.; Ganapathy, M.E. Transport of valganciclovir, a ganciclovir prodrug, via peptide transporters PEPT1 and PEPT2. J. Pharm. Sci. 2000, 89, 781-789. [CrossRef]

29. Cao, F.; Jia, J.; Yin, Z.; Gao, Y.; Sha, L.; Lai, Y.; Ping, Q.; Zhang, Y. Ethylene Glycol-Linked Amino Acid Diester Prodrugs of Oleanolic Acid for PepT1-Mediated Transport: Synthesis, Intestinal Permeability and Pharmacokinetics. Mol. Pharm. 2012, 9, 2127-2135. [CrossRef] [PubMed]

30. Cao, F.; Gao, Y.; Wang, M.; Fang, L.; Ping, Q. Propylene glycol-linked amino acid/dipeptide diester prodrugs of oleanolic acid for PepT1-mediated transport: Synthesis, intestinal permeability, and pharmacokinetics. Mol. Pharm. 2013, 10, 1378-1387. [CrossRef] [PubMed]

31. Zhou, G.B.; Kang, H.; Wang, L.; Gao, L.; Liu, P.; Xie, J.; Zhang, F.X.; Weng, X.Q.; Shen, Z.X.; Chen, J.; et al. Oridonin, a diterpenoid extracted from medicinal herbs, targets AML1-ETO fusion protein and shows potent antitumor activity with low adverse effects on $\mathrm{t}(8 ; 21)$ leukemia in vitro and in vivo. Blood 2007, 109, 3441-3450. [CrossRef] [PubMed]

32. Li, C.; Wang, E.; Cheng, Y.; Bao, J. Oridonin: An active diterpenoid targeting cell cycle arrest, apoptotic and autophagic pathways for cancer therapeutics. Int. J. Biochem. Cell Biol. 2011, 43, 701-704. [CrossRef] [PubMed]

33. Shen, J.; Zhang, D.; Zhao, Z.; Jia, L.; Zheng, D.; Liu, G.; Hao, L.; Zhang, Q.; Tian, X.; Li, C.; et al. Synthesis, characterization, in vitro and in vivo evaluation of PEGylated oridonin conjugates. Int. J. Pharm. 2013, 456, 80-86. [CrossRef] [PubMed]

34. Huang, G.M.; Sun, Y.; Ge, X.; Wan, X.; Li, C.B. Gambogic acid induces apoptosis and inhibits colorectal tumor growth via mitochondrial pathways. World J. Gastroenterol. 2015, 21, 6194-6205. [CrossRef] [PubMed]

35. Tang, X.; Zhang, P.; Ye, H.; Zhang, C.; Shen, W.; Ping, Q. Water-soluble gambogic acid PEGylated prodrugs: Synthesis, characterization, physicochemical properties and in vitro hydrolysis. Pharmazie 2008, 63, 711-717. [PubMed]

36. Adams, J.D.; Flora, K.; Goldspiel, B.R.; Wilson, J.W.; Arbuck, S.G.; Finley, R. Taxol: A history of pharmaceutical development and current pharmaceutical concerns. J. Natl. Cancer Inst. Monogr. 1993, 15, 141-147. [PubMed]

37. Skwarczynski, M.; Sohma, Y.; Noguchi, M.; Kimura, M.; Hayashi, Y.; Hamada, Y.; Kimura, T.; Kiso, Y. No auxiliary, no byproduct strategy for water-soluble prodrugs of taxoids: Scope and limitation of O-N intramolecular acyl and acyloxy migration reactions. J. Med. Chem. 2005, 48, 2655-2666. [CrossRef] [PubMed]

38. Shimoda, K.; Kubota, N. Chemo-enzymatic synthesis of ester-linked docetaxel-monosaccharide conjugates as water-soluble prodrugs. Molecules 2011, 16, 6769-6777. [CrossRef] [PubMed]

39. Estrelaa, J.M.; Ortegaa, A.; Obradora, E. Glutathione in Cancer Biology and Therapy. Crit. Rev. Clin. Lab. Sci. 2006, 43, 143-181. [CrossRef] [PubMed]

40. Balendiran, G.K.; Dabur, R.; Fraser, D. The role of glutathione in cancer. Cell Biochem. Funct. 2004, 22, 343-352.

41. Gund, M.; Khanna, A.; Dubash, N.; Damre, A.; Singh, K.S.; Satyam, A. Water-soluble prodrugs of paclitaxel containing self-immolative disulfide linkers. Bioorg. Med. Chem. Lett. 2015, 25, 122-127. [CrossRef] [PubMed]

42. Chen, J.; Du, W. Synthesis and Evaluation of Water-Soluble Etoposide Esters of Malic Acid as Prodrugs. Med. Chem. (Los. Angeles). 2013, 3, 740-747. [CrossRef]

43. Ullah, N.; Huang, Z.; Sanaee, F.; Rodriguez-Dimitrescu, A.; Aldawsari, F.; Jamali, F.; Bhardwaj, A.; Islam, N.; Velázquez-Martínez, C. NSAIDs do not require the presence of a carboxylic acid to exert their anti-inflammatory effect-Why do we keep using it? J. Enzym. Inhib. Med. Chem. 2015, 24, 1-11. [CrossRef] [PubMed]

44. Halen, P.; Murumkar, P.; Giridhar, R.; Yadav, M. Prodrug designing of NSAIDs. Mini Rev. Med. Chem. 2009, 9, 124-139. [CrossRef] [PubMed]

45. Pawar, V.; Thosani, R.; Kanhed, A.; Giridhar, R.; Yadav, M.R. Potential of Piperazinylalkylester Prodrugs of 6-Methoxy-2-Naphthylacetic Acid (6-MNA) for Percutaneous Drug Delivery. AAPS PharmSciTech 2015, 16, 518-527. [CrossRef] [PubMed] 
46. Lobo, S.; Li, H.; Farhan, N.; Yan, G. Evaluation of diclofenac prodrugs for enhancing transdermal delivery. Drug Dev. Ind. Pharm. 2014, 40, 425-432. [CrossRef] [PubMed]

47. Formica, J.V.; Regelson, W. Review of the biology of quercetin and related bioflavonoids. Food Chem. Toxicol. 1995, 33, 1061-1080. [CrossRef]

48. Montenegro, L.; Carbone, C.; Maniscalco, C.; Lambusta, D.; Nicolosi, G.; Ventura, C.A.; Puglisi, G. In vitro evaluation of quercetin-3-O-acyl esters as topical prodrugs. Int. J. Pharm. 2007, 336, 257-262. [CrossRef] [PubMed]

49. Kamat, J.P.; Devasagayam, T.P.A. Tocotrienols from palm oil as potent inhibitors of lipid peroxidation and protein oxidation in rat brain mitochondria. Neurosci. Lett. 1995, 195, 179-182. [CrossRef]

50. Newaz, M.A.; Nawal, N.N.; Rohaizan, C.H.; Muslim, N.; Gapor, A. alpha-Tocopherol increased nitric oxide synthase activity in blood vessels of spontaneously hypertensive rats. Am. J. Hypertens. 1999, 12, 839-844. [CrossRef]

51. Qureshi, A.A.; Dewitt, G.; Kramer, G.; Gapor, A. Lowering humans of serum cholesterol in hypercholesterolemic by tocotrienols. Am. J. Clin. Nutr. 1991, 53, 1021S-1026S. [PubMed]

52. Qureshi, A.A.; Bradlow, B.A.; Brace, L.; Manganello, J.; Peterson, D.M.; Pearce, B.C.; Wright, J.J.; Gapor, A.; Elson, C. Response of hypercholesterolemic subjects to administration of tocotrienols. Lipids 1995, 30, 1171-1177. [CrossRef] [PubMed]

53. Qureshi, A.A.; Bradlow, B.A.; Salser, W.A.; Brace, L.D. Novel tocotrienols of rice bran modulate cardiovascular disease risk parameters of hypercholesterolomic humans. J. Nutr. Biochem. 1997, 8, $290-298$. [CrossRef]

54. Parker, B.A.; Pearce, B.C.; Clark, R.W.; Gordon, D.A.; Wright, J.J.K. Tocotrienols regulate cholesterol production in mammalian cells by post-transcriptional suppression of 3-hydroxy-3-methylglutaryl-coenzyme a reductase. J. Biol. Chem. 1993, 268, 11230-11238. [PubMed]

55. Raederstorff, D.; Elste, V.; Aebischer, C.; Weber, P. Effect of either gamma-tocotrienol or a tocotrienol mixture on the plasma lipid profile in hamsters. Ann. Nutr. Metab. 2002, 46, 17-23. [CrossRef] [PubMed]

56. Guthrie, N.; Gapor, A.; Chambers, A.F.; Carroll, K.K. Inhibition of proliferation of estrogen receptor-negative MDA-MB-435 and -positive MCF-7 human breast cancer cells by palm oil tocotrienols and tamoxifen, alone and in combination. J. Nutr. 1997, 127, 544S-548S. [PubMed]

57. Nesaretnam, K.; Ambra, R.; Selvaduray, K.R.; Radhakrishnan, A.; Reimann, K.; Razak, G.; Virgili, F. Tocotrienol-rich fraction from palm oil affects gene expression in tumors resulting from MCF-7 cell inoculation in athymic mice. Lipids 2004, 39, 459-467. [CrossRef] [PubMed]

58. Shah, S.J.; Sylvester, P. Gamma-tocotrienol inhibits neoplastic mammary epithelial cell proliferation by decreasing Akt and nuclear factor kappaB activity. Exp. Biol. Med. 2005, 230, 235-241.

59. Akaho, N.; Takata, J.; Fukushima, T.; Matsunaga, K.; Hattori, A.; Hidaka, R.; Fukui, K.; Yoshida, M.; Fujioka, T.; Karube, Y.; et al. Preparation and In Vivo Evaluation of a Water-Soluble Prodrug for 2R- $\gamma$-Tocotrienol and as a Two-Step Prodrug for 2,7,8-Trimethyl-2S-( $\beta$-carboxyethyl)-6-hydroxychroman (S- $\gamma$-CEHC) in Rat. Drug Metab. Dispos. 2007, 35, 1502-1510. [CrossRef] [PubMed]

60. Kim, S.H.; Markovitz, B.; Trovato, R.; Murphy, B.R.; Austin, H.; Willardsen, A.J.; Baichwal, V.; Morham, S.; Bajji, A. Discovery of a new HIV-1 inhibitor scaffold and synthesis of potential prodrugs of indazoles. Bioorg. Med. Chem. Lett. 2013, 23, 2888-2892. [CrossRef] [PubMed]

61. De Miranda, P.; Blum, M. Pharmacokinetics of acyclovir after intravenous and oral administration. J. Antimicrob. Chemother. 1983, 12, 29-37. [CrossRef] [PubMed]

62. Diez-torrubia, A.; Cabrera, S.; Castro, S.D.; García-aparicio, C.; Mulder, G.; Meester, I.D.; Camarasa, M.; Balzarini, J.; Velázquez, S. Novel water-soluble prodrugs of acyclovir cleavable by the dipeptidyl-peptidase IV (DPP IV/CD26) enzyme. Eur. J. Med. Chem. 2013, 70, 456-468. [CrossRef] [PubMed]

63. Zhou, J.; Tao, P.; Fisher, J.F.; Shi, Q.; Mobashery, S.; Schlegel, H.B. QM/MM Studies of the Matrix Metalloproteinase 2 (MMP2) Inhibition Mechanism of (S)-SB-3CT and its Oxirane Analogue. J. Chem. Theory Comput. 2010, 6, 3580-3587. [CrossRef] [PubMed]

64. Gooyit, M.; Lee, M.; Schroeder, V.A.; Ikejiri, M.; Suckow, M.A.; Mobashery, S.; Chang, M. Selective water-soluble gelatinase inhibitor prodrugs. J. Med. Chem. 2011, 54, 6676-6690. [CrossRef] [PubMed]

65. Lee, C.W.; Hong, D.H.; Han, S.B.; Jung, S.-H.; Kim, H.C.; Fine, R.L.; Lee, S.-H.; Kim, H.M. A novel stereo-selective sulfonylurea, 1-[1-(4-aminobenzoyl)-2,3-dihydro-1H-indol-6-sulfonyl]-4-phenyl-imidazolidin-2-one, has antitumor efficacy in in vitro and in vivo tumor models. Biochem. Pharmacol. 2002, 64, 473-480. [CrossRef] 
66. Lee, K.-C.; Venkateswararao, E.; Sharma, V.K.; Jung, S.-H. Investigation of amino acid conjugates of (S)-1-[1-(4-aminobenzoyl)-2,3-dihydro-1H-indol-6-sulfonyl]-4-phenyl-imidazolidin-2-one (DW2282) as water soluble anticancer prodrugs. Eur. J. Med. Chem. 2014, 80, 439-446. [CrossRef] [PubMed]

67. Hirabayashi, H.; Takahashi, T.; Fujisaki, J.; Masunaga, T.; Sato, S.; Hiroi, J.; Tokunaga, Y.; Kimura, S.; Hata, T. Bone-specific delivery and sustained release of diclofenac, a non-steroidal anti-inflammatory drug, via bisphosphonic prodrug based on the Osteotropic Drug Delivery System (ODDS). J. Control. Release 2001, 70, 183-191. [CrossRef]

68. Wang, D.; Miller, S.C.; Kopečková, P.; Kopeček, J. Bone-targeting macromolecular therapeutics. Adv. Drug Deliv. Rev. 2005, 57, 1049-1076. [CrossRef] [PubMed]

69. Murphy, M.B.; Hartgerink, J.D.; Goepferich, A.; Mikos, A.G. Synthesis and in vitro hydroxyapatite binding of peptides conjugated to calcium-binding moieties. Biomacromolecules 2007, 8, 2237-2243. [CrossRef] [PubMed]

70. Ishizaki, J.; Waki, Y.; Takahashi-Nishioka, T.; Yokogawa, K.; Miyamoto, K.I. Selective drug delivery to bone using acidic oligopeptides. J. Bone Miner. Metab. 2009, 27, 1-8. [CrossRef] [PubMed]

71. Sarig, S. Aspartic acid nucleates the apatite crystallites of bone: A hypothesis. Bone 2004, 35, $108-113$. [CrossRef] [PubMed]

72. Ouyang, L.; Zhang, J.; Pan, J.; Yan, L.; Guo, L. Synthesis and preliminary evaluation in vitro of novel naproxen-dendritic peptide conjugates. Drug Deliv. 2009, 16, 348-356. [CrossRef] [PubMed]

73. Kaul, M.; Mark, L.; Zhang, Y.; Parhi, A.K.; LaVoie, E.J.; Pilch, D.S. An FtsZ-targeting prodrug with oral antistaphylococcal efficacy in vivo. Antimicrob. Agents Chemother. 2013, 57, 5860-5869. [CrossRef] [PubMed]

74. Kaul, M.; Mark, L.; Zhang, Y.; Parhi, A.K.; Lavoie, E.J.; Pilch, D.S. Pharmacokinetics and in vivo antistaphylococcal efficacy of TXY541, a 1-methylpiperidine-4-carboxamide prodrug of PC190723. Biochem. Pharmacol. 2013, 86, 1699-1707. [CrossRef] [PubMed]

75. Monneret, C. Histone deacetylase inhibitors. Eur. J. Med. Chem. 2005, 40, 1-13. [CrossRef] [PubMed]

76. Dokmanovic, M.; Clarke, C.; Marks, P.A. Histone Deacetylase Inhibitors: Overview and Perspectives. Mol. Cancer Res. 2007, 5, 981-989. [CrossRef] [PubMed]

77. Thomas, M.; Clarhaut, J.; Tranoy-Opalinski, I.; Gesson, J.P.; Roche, J.; Papot, S. Synthesis and biological evaluation of glucuronide prodrugs of the histone deacetylase inhibitor CI-994 for application in selective cancer chemotherapy. Bioorg. Med. Chem. 2008, 16, 8109-8116. [CrossRef] [PubMed]

78. Vignaroli, G.; Zamperini, C.; Dreassi, E.; Radi, M.; Angelucci, A.; Sanità, P.; Crespan, E.; Kissova, M.; Maga, G.; Schenone, S.; et al. Pyrazolo[3,4-d]pyrimidine prodrugs: Strategic optimization of the aqueous solubility of dual Src/Abl inhibitors. ACS Med. Chem. Lett. 2013, 4, 622-626. [CrossRef] [PubMed]

79. Arora, A.; Scholar, E.M. Role of tyrosine kinase inhibitors in cancer therapy. J. Pharmacol. Exp. Ther. 2005, 315, 971-979.

80. Debele, T.; Peng, S.; Tsai, H.-C. Drug Carrier for Photodynamic Cancer Therapy. Int. J. Mol. Sci. 2015, 16, 22094-22136. [CrossRef] [PubMed]

81. Macdonald, I.J.; Dougherty, T.J. Basic principles of photodynamic therapy. J. Porphyr. Phthalocyanines 2001, 5, 105-129. [CrossRef]

82. Noguchi, M.; Skwarczynski, M.; Prakash, H.; Hirota, S.; Kimura, T.; Hayashi, Y.; Kiso, Y. Development of novel water-soluble photocleavable protective group and its application for design of photoresponsive paclitaxel prodrugs. Bioorg. Med. Chem. 2008, 16, 5389-5397. [CrossRef] [PubMed]

83. Binderup, E.; Björkling, F.; Hjarnaa, P.V.; Latini, S.; Baltzer, B.; Carlsen, M.; Binderup, L. EB1627: A soluble prodrug of the potent anticancer cyanoguanidine CHS828. Bioorg. Med. Chem. Lett. 2005, 15, 2491-2494. [CrossRef] [PubMed]

84. Erez, R.; Segal, E.; Miller, K.; Satchi-Fainaro, R.; Shabat, D. Enhanced cytotoxicity of a polymer-drug conjugate with triple payload of paclitaxel. Bioorg. Med. Chem. 2009, 17, 4327-4335. [CrossRef] [PubMed]

85. Satchi-Fainaro, R.; Hailu, H.; Davies, J.W.; Summerford, C.; Duncan, R. PDEPT: Polymer-Directed Enzyme Prodrug Therapy. 2. HPMA Copolymer- $\beta$-lactamase and HPMA Copolymer-C-Dox as a Model Combination. Bioconjugate Chem. 2003, 14, 797-804. [CrossRef] [PubMed]

86. Wani, M.C.; Ronman, P.E.; Lindley, J.T.; Wall, M.E. Plant antitumor agents. 18. Synthesis and biological activity of camptothecin analogs. J. Med. Chem. 1980, 23, 554-560. [CrossRef] [PubMed]

87. Ling, Y.H.; Andersson, B.S.; Nelson, J.A. DNA topoisomerase I as a site of action for 10-hydroxycamptothecin in human promyelocytic leukemia cells. Cancer Biochem. Biophys. 1990, 11, 23-30. [PubMed] 
88. Leu, Y.L.; Chen, C.S.; Wu, Y.J.; Chern, J.W. Benzyl ether-linked glucuronide derivative of 10-hydroxycamptothecin designed for selective camptothecin-based anticancer therapy. J. Med. Chem. 2008, 51, 1740-1746. [CrossRef] [PubMed]

89. Kim, J.H.; Lee, H.J.; Yeon, S.C.; Choi, D.H.; Lee, S.S.; Kang, J.K.; Chae, C.H.; Paik, N.W.; Lee, K.H.; Cho, M.H. Antioxidative Effects of 7-Hydroxy-3-Methoxy-Cadalene Extracted from Zelkova serrata on Butanone-induced Oxidative Stress in A/J Mice. Phyther. Res. 2004, 18, 425-427. [CrossRef] [PubMed]

90. Lee, H.Y.; Kwon, J.T.; Koh, M.; Cho, M.H.; Park, S.B. Enhanced efficacy of 7-hydroxy-3-methoxycadalene via glycosylation in in vivo xenograft study. Bioorg. Med. Chem. Lett. 2007, 17, 6335-6339. [CrossRef] [PubMed]

91. Day, T.P.; Sil, D.; Shukla, N.M.; Anbanandam, A.; Day, V.W.; David, S.A. Imbuing aqueous solubility to amphotericin B and nystatin with a vitamin. Mol. Pharm. 2010, 8, 297-301. [CrossRef] [PubMed]

92. Hochdörffer, K.; Abu Ajaj, K.; Schäfer-Obodozie, C.; Kratz, F. Development of novel bisphosphonate prodrugs of doxorubicin for targeting bone metastases that are cleaved $\mathrm{pH}$ dependently or by cathepsin B: Synthesis, cleavage properties, and binding properties to hydroxyapatite as well as bone matrix. J. Med. Chem. 2012, 55, 7502-7515. [CrossRef] [PubMed]

93. Moktan, S.; Ryppa, C.; Kratz, F.; Raucher, D. A thermally responsive biopolymer conjugated to an acid-sensitive derivative of paclitaxel stabilizes microtubules, arrests cell cycle, and induces apoptosis. Investig. New Drugs 2012, 30, 236-248. [CrossRef] [PubMed]

94. Schultz, C. Prodrugs of biologically active phosphate esters. Bioorg. Med. Chem. 2003, 11, 885-898. [CrossRef]

95. Wiemer, A.; Wiemer, D. Prodrugs of phosphonates and phosphates: Crossing the membrane barrier. Top. Curr. Chem. 2014, 360, 115-160.

96. Ghosh, K.; Mazumder Tagore, D.; Anumula, R.; Lakshmaiah, B.; Kumar, P.P.B.S.; Singaram, S.; Matan, T.; Kallipatti, S.; Selvam, S.; Krishnamurthy, P.; et al. Crystal structure of rat intestinal alkaline phosphatase-Role of crown domain in mammalian alkaline phosphatases. J. Struct. Biol. 2013, 184, 182-192. [CrossRef] [PubMed]

97. Hecker, S.J.; Erion, M.D. Prodrugs of Phosphates and Phosphonates. J. Med. Chem. 2008, 51, $2328-2345$. [CrossRef] [PubMed]

98. Krise, J.P.; Stella, V.J. Prodrugs of Phosphates, Phosphonates, and Phosphinates. Adv. Drug Deliv. Rev. 1996, 19, 287-310. [CrossRef]

99. Degoey, D.A.; Grampovnik, D.J.; Flosi, W.J.; Marsh, K.C.; Wang, X.C.; Klein, L.L.; Mcdaniel, K.F.; Liu, Y.; Long, M.A.; Kati, W.M.; Molla, A.; Kempf, D.J. Water-Soluble Prodrugs of the Human Immunodeficiency Virus Protease Inhibitors Lopinavir and Ritonavir Water-Soluble Prodrugs of the Human Immunodeficiency Virus Protease Inhibitors Lopinavir and Ritonavir. J. Med. Chem. 2009, 52, 2964-2970. [CrossRef] [PubMed]

100. Flores-ramos, M.; Ibarra-velarde, F.; Hernández-campos, A.; Vera-montenegro, Y.; Jung-cook, H.; Cantó-alarcón, G.J.; Misael, L.; Castillo, R. A highly water soluble benzimidazole derivative useful for the treatment of fasciolosis. Bioorg. Med. Chem. Lett. 2014, 24, 5814-5817. [CrossRef] [PubMed]

101. Hachet-Haas, M.; Balabanian, K.; Rohmer, F.; Pons, F.; Franchet, C.; Lecat, S.; Chow, K.Y.C.; Dagher, R.; Gizzi, P.; Didier, B.; et al. Small Neutralizing Molecules to Inhibit Actions of the Chemokine CXCL12. J. Biol. Chem. 2008, 283, 23189-23199. [CrossRef] [PubMed]

102. Gasparik, V.; Daubeuf, F.; Hachet-Haas, M.; Rohmer, F.; Gizzi, P.; Haiech, J.; Galzi, J.L.; Hibert, M.; Bonnet, D.; Frossard, N. Prodrugs of a CXC chemokine-12 (CXCL12) neutraligand prevent inflammatory reactions in an asthma model in vivo. ACS Med. Chem. Lett. 2012, 3, 10-14. [CrossRef] [PubMed]

103. Kumpulainen, H.; Järvinen, T.; Mannila, A.; Leppänen, J.; Nevalainen, T.; Mäntylä, A.; Vepsäläinen, J.; Rautio, J. Synthesis, in vitro and in vivo characterization of novel ethyl dioxy phosphate prodrug of propofol. Eur. J. Pharm. Sci. 2008, 34, 110-117. [CrossRef] [PubMed]

104. Lee, M.; Chen, Z.; Tomlinson, B.N.; Gooyit, M.; Hesek, D.; Juárez, M.R.; Nizam, R.; Boggess, B.; Lastochkin, E.; Schroeder, V.A.; et al. Water-Soluble MMP-9 Inhibitor Reduces Lesion Volume after Severe Traumatic Brain Injury. ACS Chem. Neurosci. 2015, 10, 1658-1664. [CrossRef] [PubMed]

105. Charifson, P.S.; Grillot, A.L.; Grossman, T.H.; Parsons, J.D.; Badia, M.; Bellon, S.; Deininger, D.D.; Drumm, J.E.; Gross, C.H.; LeTiran, A.; et al. Novel dual-targeting benzimidazole urea inhibitors of DNA gyrase and topoisomerase IV possessing potent antibacterial activity: Intelligent design and evolution through the judicious use of structure-guided design and structure-activity relationships. J. Med. Chem. 2008, 51, 5243-5263. [CrossRef] [PubMed] 
106. Grossman, T.H.; Bartels, D.J.; Mullin, S.; Gross, C.H.; Parsons, J.D.; Liao, Y.; Grillot, A.-L.; Stamos, D.; Olson, E.R.; Charifson, P.S.; Mani, N. Dual targeting of GyrB and ParE by a novel aminobenzimidazole class of antibacterial compounds. Antimicrob. Agents Chemother. 2007, 51, 657-666. [CrossRef] [PubMed]

107. O’Dowd, H.; Shannon, D.E.; Chandupatla, K.R.; Dixit, V.; Engtrakul, J.J.; Ye, Z.; Jones, S.M.; O’Brien, C.F.; Nicolau, D.P.; Tessier, P.R.; et al. Discovery and Characterization of a Water-Soluble Prodrug of a Dual Inhibitor of Bacterial DNA Gyrase and Topoisomerase IV. ACS Med. Chem. Lett. 2015, 6, 822-826. [CrossRef] [PubMed]

108. Oslob, J.D.; Heumann, S.A.; Yu, C.H.; Allen, D.A.; Baskaran, S.; Bui, M.; Delarosa, E.; Fung, A.D.; Hashash, A.; Hau, J.; et al. Water-soluble prodrugs of an Aurora kinase inhibitor. Bioorg. Med. Chem. Lett. 2009, 19, 1409-1412. [CrossRef] [PubMed]

109. Mortlock, A.A.; Keen, N.J.; Jung, F.H.; Heron, N.M.; Foote, K.M.; Wilkinson, R.W.; Green, S. Progress in the development of selective inhibitors of aurora kinases. Curr. Top. Med. Chem. 2005, 5, 807-821. [CrossRef] [PubMed]

110. Chen, X.Q.; Venkatesh, S. Miniature device for aqueous and non-aqueous solubility measurements during drug discovery. Pharm Res 2004, 21, 1758-1761. [CrossRef] [PubMed]

111. Hemenway, J.N.; Nti-Addae, K.; Guarino, V.R.; Stella, V.J. Preparation, characterization and in vivo conversion of new water-soluble sulfenamide prodrugs of carbamazepine. Bioorg. Med. Chem. Lett. 2007, 17, 6629-6632. [CrossRef] [PubMed]

112. Liu, H.-F.; Wan, N.; Huan, M.-L.; Jia, Y.-Y.; Yuan, X.-F.; Zhou, S.-Y.; Zhang, B.-L. Enhanced water-soluble derivative of PC407 as a novel potential COX-2 inhibitor injectable formulation. Bioorg. Med. Chem. Lett. 2014, 24, 4794-4797. [CrossRef] [PubMed]

113. Lin, J.K.; Pan, M.H.; Lin-Shiau, S.Y. Recent studies on the biofunctions and biotransformations of curcumin. Biofactors 2000, 13, 153-158. [CrossRef] [PubMed]

114. Pan, M.H.; Huang, T.M.; Lin, J.K. Biotransformation of curcumin through reduction and glucuronidation in mice. Drug Metab. Dispos. 1999, 27, 486-494. [PubMed]

115. Kawakishi, S. Antioxidative of the P-Diketone Moiety in the Mechanism of Tetrahydrocurcumin. Science 1996, 52, 519-525.

116. Plyduang, T.; Lomlim, L.; Yuenyongsawad, S.; Wiwattanapatapee, R. Carboxymethylcellulosetetrahydrocurcumin conjugates for colon-specific delivery of a novel anti-cancer agent, 4-amino tetrahydrocurcumin. Eur. J. Pharm. Biopharm. 2014, 88, 351-360. [CrossRef] [PubMed]

117. Patel, A.R.; Vavia, P.R. Preparation and Evaluation of Taste Masked Famotidine Formulation Using Drug/ $\beta$-cyclodextrin/Polymer Ternary Complexation Approach. AAPS PharmSciTech 2008, 9, 544-550. [CrossRef] [PubMed]

118. Vijayaraj, S.; Omshanthi, B.; Anitha, S.; Sampath Kumar, K.P. Synthesis and Characterization of Novel Sulphoxide prodrug of Famotidine. Indian J. Pharm. Educ. Res. 2014, 48, 35-44. [CrossRef]

119. Rocamora, R. A review of the efficacy and safety of eslicarbazepine acetate in the management of partial-onset seizures. Ther. Adv. Neurol. Disord. 2015, 8, 178-186. [CrossRef] [PubMed]

120. Ben-Menachem, E. Eslicarbazepine Acetate: A Well-Kept Secret? Epilepsy Curr. 2010, 10, 7-8. [PubMed]

121. Mueller, S.W.; Moore, G.D.; Maclaren, R. Fospropofol Disodium for Procedural Sedation: Emerging Evidence of its Value? Clin. Med. Insights Ther. 2010, 2, 513-522.

122. Boules, R.; Szkiladz, A.; Nogid, A. Fospropofol disodium (lusedra) injection for anesthesia-care sedation: a clinical review. Pharm. Ther. 2012, 37, 395-422.

123. Ishikawa, T.; Matsunaga, N.; Tawada, H.; Kuroda, N.; Nakayama, Y.; Ishibashi, Y.; Tomimoto, M.; Ikeda, Y.; Tagawa, Y.; Iizawa, Y.; et al. TAK-599, a novel N-phosphono type prodrug of anti-MRSA cephalosporin T-91825: Synthesis, physicochemical and pharmacological properties. Bioorg. Med. Chem. 2003, 11, 2427-2437. [CrossRef]

124. Flanagan, S.; Bartizal, K.; Minassian, S.L.; Fang, E.; Prokocimer, P. In vitro, in Vivo, and clinical studies of tedizolid to assess the potential for peripheral or central monoamine oxidase interactions. Antimicrob. Agents Chemother. 2013, 57, 3060-3066. [PubMed]

125. Rybak, J.M.; Roberts, K. Tedizolid Phosphate: A Next-Generation Oxazolidinone. Infect. Dis. Ther. 2015, 4, 1-14.

(C) 2015 by the authors; licensee MDPI, Basel, Switzerland. This article is an open access article distributed under the terms and conditions of the Creative Commons by Attribution (CC-BY) license (http://creativecommons.org/licenses/by/4.0/). 